\title{
The Changing Nature of Expatriation: The Emerging Role of Knowledge Transfer Readiness
}

\author{
Dian Prihadyanti ${ }^{1}$ D $\cdot$ Karlina Sari $^{1} \cdot$ Dudi Hidayat $^{1} \cdot$ Nur Laili $^{1} \cdot$ Budi Triyono $^{1}$. \\ Chichi Shintia Laksani²
}

Received: 29 January 2020 / Accepted: 24 February 2021 / Published online: 25 March 2021

(c) The Author(s), under exclusive licence to Springer Science+Business Media, LLC, part of Springer Nature 2021

\begin{abstract}
Expatriate is one of the potential sources of knowledge for firms to increase their capability in creating innovation. Currently, Indonesia has a relatively small number of expatriates but the figure tends to increase overtime. This country has experienced a changing nature of expatriation that brings consequences to several conditions for the achievement of successful knowledge transfer (KT) from expatriates to local employee in Indonesian local firms. This paper proposes a new concept namely Knowledge Transfer Readiness (KTR) which is beneficial in helping the firms to deal with the changing nature. Combining grounded research and multiple case studies to apply this concept to the Indonesian local firms, it is argued that not all of the elements in KTR's dimensions must be fulfilled in excellent conditions. Weak elements from the source's side can be surmounted by fulfilling excellent condition of recipient's side, and vice versa. Nevertheless, there are elements that must be fulfilled in excellent condition of both sides, or becomes absolute requirements solely for the expatriates. The fulfillment of KTR's elements influences the relationship qualities between expatriates and local employees to achieve Knowledge Transfer Quality (KTQ). The KTQ includes the amount and the accuracy of knowledge and depth of understanding, so it can be a new option of qualitative indicator to measure the success of KT.
\end{abstract}

Keywords Knowledge Transfer · Expatriation · Human Resources Management · Strategic Management · Knowledge Sharing · Innovation Capability

Dian Prihadyanti

dian.prihadyanti@gmail.com

1 Research Center for Policy and Management of Science, Technology, and Innovation, Indonesian Institute of Sciences, Jakarta, Indonesia

2 Center for Science and Technology Utilization and Innovation, Indonesian Institute of Sciences, West Java, Indonesia 


\section{Introduction}

Knowledge has become one of the most important resources firms' survivals (Teece et al., 1997). Knowledge and its rapid change has also become a key driver of competitiveness (Parcero \& Ryan, 2017). Expatriate is one of the potential external sources for companies to improve knowledge and to increase technological capability for creating innovation (Chang et al., 2012) through expatriation (Downes \& Thomas, 2000). This can be enabled through knowledge transfer (KT). KT is one of the sources of innovation (Alexander \& Childe, 2013; Weidenfeld et al., 2010) through collaboration in value co-creation (Ramaswamy, 2009). Literature indicates that $\mathrm{KT}$ is a phenomenon contributing to organizational outcomes that involve both internal and external resources in developed and developing countries (Cassiman \& Veugelers, 2006) in (Zulkifli et al., 2019)

The expected role of expatriation is to ensure that expatriate is able to implement and to attain global business strategies, including the transfer of knowledge, coordination and control of foreign operations/units, and human resources development (Kühlmann \& Hutchings, 2010). Nature of expatriation can be described from its purpose, activities during the process, actors, outcomes, and contextual factors. Considering dynamic change in every country, these elements may experience changes that bring several challenges for the expatriation. The challenges come from several limiting conditions faced by firms employing expatriates, mostly driven by dynamic business environment.

Developing countries, of which the industrial structures are usually dominated by companies with low technological capabilities, have limited sources of knowledge due to the investment capability (Figueiredo, 2010). Whereas, the dynamic capabilities framework suggests that firms running in the atmosphere of rapid technological change require particular foundations and means for wealth creation. The dynamic capabilities framework analyzes the sources and methods of wealth creation by firms operating in rapid technological change environment. (Teece et al., 1997). (Lim \& Lee, 2001) suggest that latecomers companies need to catch up on their technology backwardness, one of which is conducted through KT. However, KT itself is a complex process with several obstacles, which limiting the ideal conditions for KT through expatriates. Due to its unique social characteristics and nature of expatriation, each country may have different conditions. Therefore, there is no generic KT strategy for all countries.

Indonesia, as a developing country, has a relatively small number of expatriates, but it tends to increase overtime (Fig. 1). Companies that employ the expatriates are not only MNCs, but also local ones. During this Covid-19 pandemic, the number of applications of expatriates is predicted to decrease. However, the utilization of expatriate is still supported by the Indonesian government. This can be seen from the issuance of related policies, such as -the most recent - the Omnibus Law. In fact, the KT process has not been running easily and smoothly, especially in local companies, due to four limiting conditions:

a) Limited number of expatriates in specific competence. Thus, local firms experience difficulty in finding expatriates who match their needs. It has changed 


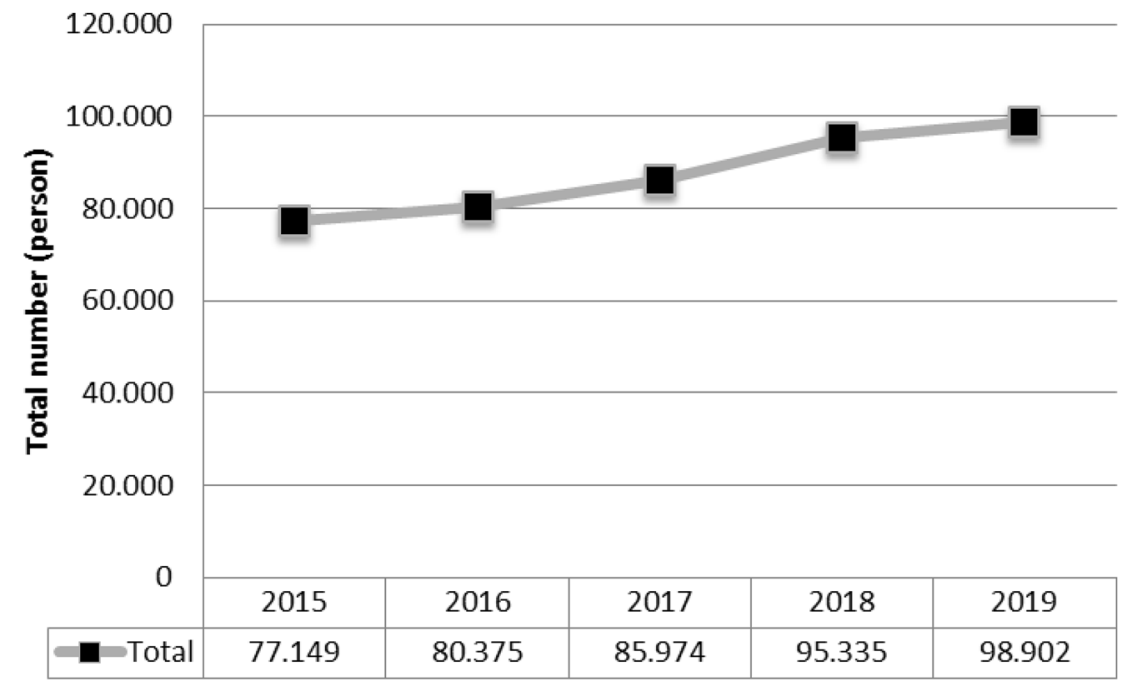

Source: Ministry of Workforce, Republic of Indonesia

Fig. 1 Total number of expatriates in Indonesia (2015-2019)

the nature of the recruitment and selection (RandS). Even when the firms are able to identify the ideal expatriate, they cannot afford to pay the salary. Therefore, the expatriation process is usually accelerated to minimize the financial resources used and allocate it for the salary payment. The local firms usually strive to find another potential benefit that can be gained from the expatriates. This also influences the assignment stage of expatriation which greatly needs an innovative strategy so the local firms will be able to absorb the important knowledge from the expatriate.

b) Limited resources of the company. In regard to their rare expertise, expatriate usually has high salary standard than local employee, which is less affordable by Indonesian companies. As a consequence, firms need to reallocate their budget so they are able to pay the expatriates, i.e. through cost reduction. The limited resources also become the reason to lower the firm's expectation on the expatriate. This influences the nature of RandS as a part of expatriation process. Generally, expatriate's RandS implements coffee-machine theory (Harris \& Brewster, 1999). At present, especially for Indonesian local companies, this theory seems to be less suitable since it needs more aspects to be considered and complex decision-making process.

c) Complex expatriation process. Indonesian local companies generally apply a fairly rigorous selection process for expatriate candidates. This usually differs based on number of the expatriates and purpose of employment. This encourages the firms to modify some expatriation so it can be more effective and efficient. The modification varies towards the way how the expatriate will be assigned in a firm through single and multiple stage of expatriation which have different complexity (Prihadyanti, 2019). 
d) Government policy. In Indonesia, government regulation for expatriate in private sectors usually has great effect on expatriation process. This occurs in the form of quota restrictions and administrative requirements. The quota restrictions greatly affect the expatriation when the expatriates come in groups. In this case, when one of the expatriates failed to arrive, the overall activities will be affected, which will bring delays or even stop the project. This influences the RandS stages and also the next stages of expatriation. Meanwhile, there is also bureaucracy problem due to inflexible administrative requirements. This gives effect when an expatriate cancel out his/her arrival due to several reasons. In this case, a firm cannot easily replace the expatriate with other ones with similar competences, but the firm must repeat the process from the beginning. This usually impact on late arrival of expatriate. Even more, the process takes several months to be completed, even when an expatriate will only come for several days. This usually brings loss for the firms. These obstacles stimulate firms to give response and proactive action during the process. These show that government policy affects expatriation process and takes part in changing the nature of the process.

Based on the explanation, in Indonesia, the limiting conditions affect the expatriation and change its nature in terms of purpose, process, actors, and contextual factors. In regard with the KT purpose, this also brings consequences to the strategy. Different conditions lead to different KT strategy that should be applied by firms that employ expatriates. This strategy must have concerns on several aspects from the source and recipient of knowledge that should be controlled by the company as much as possible. The strategy should be intended to obtain successful KT, especially in conditions that do not allow optimal result.

This paper proposes a new concept namely Knowledge Transfer Readiness (KTR) which embraces dimensions and elements needed to be prepared to be able to conduct successful KT-which is further named as KTR-in several limiting conditions. In addition, this paper describes and analyzes why these dimensions and elements are important to achieve successful KT and builds understanding under what conditions the company-in this case is the local companies in Indonesia-needs to optimize the readiness of knowledge source and/or receiver when the company faces various limitations, that at the same time forms the changing nature of expatriation to generate innovation through KT from expatriate to local employee. Literature discussing this topic is still rarely found. Therefore, this paper contributes to theory in area of expatriation in regard with KT which then can fill knowledge gap related to KT and expatriation in developing countries, or any other countries in which companies experience the same conditions and/or problems. Different from other concepts of readiness in regard with knowledge, for example knowledge management readiness (KMR) (Sultan \& Bach, 2015), change readiness in knowledge sharing (Valmohammadi \& Amidi, 2020), or knowledge transfer plan (Zulkifli et al., 2019), this concept focuses more on how to prepare for successful KT in a holistic manner considering the involvement of expatriate and local employee. Applying the KTR to analyze the condition of six case studies in Indonesian local firms, this concept can help to understand the importance of each elements of readiness as part of KT mechanism that can lead to either successful or failed KT. The results of this study also have practical contribution in drawing up the KT plan as part of KT's strategy including 
RandS of expatriate, especially when there are limitations that complicate the formation of prerequisite conditions for conducting KT.

\section{Literature Review}

Before conducting KT, companies usually create plans so that KT can run successfully. (Zulkifli et al., 2019) stated that there are several principles that must be held to perform KT effectively. These principles include the importance of holistic approach for KT that considers technology, generational differences, cultural diversity, and learning style; the principle that one size does not fit all; the principle that KT must be timely, relevant, and efficient; the involvement of the sources and the recipients at each stage of the KT process; as well as the importance of communication. In the process of KT itself, both sources and recipients can play a role in the planning and implementation of strategies (Reardon et al., 2006). These refer to the importance of planning and preparation in conducting KT, and leads to the need for 'readiness' as its prerequisites.

Recently, various terms regarding readiness in relation with knowledge have been developed, such as technology readiness (Parasuraman, 2000 in Vize, 2013), e-readiness (Aboelmaged, 2014), change readiness (Valmohammadi \& Amidi, 2020), and knowledge management readiness (Sultan \& Bach, 2015). In essence, readiness can be defined as the ability of individual, organizational, or country unit to be prepared, willing to, conduct, and benefit from any entrance of object or activities. In the context of KT, the readiness refers to the ability of a unit to be prepared, willing to, conducting, and benefiting from the activity. Later, this readiness is called Knowledge Transfer Readiness (KTR).

There are several concepts which are almost similar with KTR. Knowledge Management Readiness (KMR) developed by (Sultan and Bach, 2015) discusses seven different factors influencing the current KM practices of organizations. These seven factors include, (i) technology tools for communication, (ii) identify critical knowledge for business activities, (iii) strategic program, (iv) business intelligence information, (v) identification of the right knowledge, (vi) management constantly reviews and acts and (vii) organization 's intellectual capital. Another related concept is change readiness for knowledge acquisition (Valmohammadi \& Amidi, 2020), defined as a belief, intention, and attitude concerning the extent to which change is needed with regard to the transformation of beliefs into actions. This concept represents the indicator of positive attitudes for change in the context of knowledge acquisition. Another research which indicated importance factors which are needed for successful KT was developed by (Hsu 2012) using quantitative method, in which he almost failed to statistically prove the hypotheses. The KTR concept has more focus on qualitatively identifying and measuring the important factors needed for successful KT.

Knowledge is an organizational asset that must be managed properly to achieve competitive advantage. This knowledge is needed to establish adequate innovation capabilities in order to carry out innovation activities needed by companies to remain competitive when dealing with business competition. (Lawson \& Samson, 
2001) define innovation capability as the ability to continuously transform knowledge and ideas into new products, processes and systems that benefit the company and its stakeholders. The ability of the company's innovation is basically an accumulation of innovation capabilities from individuals in the company (Tortoriello, 2014). Therefore, ability to acquire and use external knowledge from these individuals is very important in the process (Cohen \& Levinthal, 1990). This invigorates many firms to invite external parties including expatriates to be involved in innovation process (Abbate et al., 2013). The expatriates are often involved in developing technological capabilities in order to create an innovation. KT allows the formation and creation occur in this process. In the context of technological capability, (Figueiredo et al., 2010) divide the level of technological capability into five levels, from basic operational to advanced innovator. This categorization indicates that the ability of innovation cannot be obtained without firstly mastering basic skills related to operational aspects in the routine work in the company. Therefore, to be able to master the knowledge needed to become an advanced innovator-or in other words to master the knowledge that forms innovation capability- it is necessary to master the knowledge in the first place, forming operational or 'production' capability. Thus it can be concluded that the output of KT can occur in form of innovation capability which then resulting in innovation as its outcome.

(Davenport \& Prusak, 1998) stated that KT involves actions for knowledge transmission and absorption. The transmission occurs when the source of knowledge sends knowledge to potential recipients, while the absorption occurs when the knowledge is received and internalized by a person or a group as the recipient. KT process can be understood through two levels-individual level and organizational level. KT in an organization can be defined as the process of one unit (group, department or division) affecting other units in the organization (Argote \& Ingram, 2000). At the organizational level, KT manifests through changes in knowledge in an organization. At the individual level, KT can be defined as a process for exchanging knowledge, both one-way and two-way between the knowledge owner (source / sender) and the knowledge recipient (recipient / receiver). Meanwhile, the intraorganization KT at the individual level can be defined as the process of how the knowledge obtained from a situation can then be applied (or failed to apply) to other situations (Singley and Anderson, 1989). This is related to know-how which can be held by an individual or a collective group (Bonache et al., 2010). Collective knowledge is associated with capabilities as the outcome of knowledge integration. It refers to what a group of people working together is capable of doing. Both collective and individual knowledge can be explicit or tacit which are different but complementary (Grant, 1996).

A firm conducts KT to improve its stock of knowledge. KT itself has various definitions. KT in firm level can be defined as a learning process that occurs when one unit (group / department / division) is influenced by the knowledge and expertise of other units (Argote \& Ingram, 2000). Another definition is stated by (Szulanski, 2003) which proposed KT as a two-way process for exchanging knowledge between sender (source) and receiver (recipient). The exchange of knowledge alone can basically occur in one direction or two directions between the owner and recipient of knowledge (Ismail, 2015). The types of transferred knowledge is varied, from 
management knowledge, cultural knowledge, technical knowledge, sales and marketing knowledge, product knowledge, human resource management knowledge, to accounting / finance knowledge (Riusala \& Suutari, 2004).

KT needs the right mechanism, which depends on the conditions of the source and the recipients of knowledge. Face-to-face meeting is considered as the most effective KT mechanism (Dixon, 2000; Wenger et al., 2002). This is the basis for the company to bring in certain experts in the KT process. With the physical presence of experts, explicit knowledge and tacit knowledge can be delivered thoroughly.

Besides seeking for the most suitable expatriates, companies also basically need to prepare co-workers who are suitable with the expatriate and possess adequate competencies. This is because KT is a process that involves transferor and transferee, where in this case the transferor is an expatriate, while the transferee is a workforce in the host company. When this KT occurs in a local company, the role of transferee is hold by a local employee as the co-worker of the expatriate. Therefore, the local employee also needs to be prepared because KT does not merely occur only by the presence of the expatriate. Even more, there are several limitations that drive changes in the nature of expatriation and at the same time become challenges for local companies to achieve successful KT.

(Szulanski, 2003) describes KT as a sequential process between source (sender/ provider) and recipient (receiver) consisting four stages: initiation, implementation, ramp-up, and integration. In the initiation stage, the transfer process begins with needs identification and determination of knowledge that can meet the needs (Szulanski, 1996). In identifying needs, the search for potential solutions is carried out and may lead to the discovery of knowledge considered superior. In achieving these superior results, the question on "how" the achieved results can be obtained. When the needs and solutions have been identified, the transfer process is possible to be investigated. The process of gathering information and evaluation can take months (Teece, 1976) and leads to sequential or random transfer decision (Cohen et al., 1972). When KT is not possible, this stage cannot continue to implementation stage. If KT is possible to be conducted, then the initiation stage can continue to the implementation stage.

At the implementation stage, the transferred resources begin to be transferred from the source of knowledge to the recipients and to the third parties if possible. The process forms a social bond between the two parties. This stage is carried out to meet the needs of the recipient, to overcome the problems experienced in the previous stage, or to minimize the difficulties experienced by the recipient when new knowledge is introduced. Activities in the implementation stage usually end or begin to decrease when the recipient starts using the transferred knowledge (Szulanski, 2003).

The next stage-ramp-up stage, is entered when the recipient starts using the knowledge that has been transferred. With the implementation of KT, the recipient has the expectation of performance improvements to be achieved. In the performance improvement process, there may be problems that hinder this achievement. Nevertheless, the recipient is encouraged to overcome the problem. When the problem can be overcome, gradually the expected performance targets can be achieved (Szulanski, 2003). In this stage, it can be argued that there is possibility 
to rewind to the implementation stage, in order to deepen or to select other similar or complementary knowledge meeting the needs defined in the initiation stage. (Fig. 2)

The last stage in the KT process is the integration stage. After the recipient achieves satisfactory results, the integration phase begins. When gradual use of knowledge has become a new routine, this routine becomes a social pattern (Berger \& Luckman, 1966). Then the knowledge is built up in the recipient and the recipient's activities become new routine introduced in the organization. The received knowledge may change into different activities in each individual, but gradually, these activities are coordinated and transform into new, settled habits. The new behavior becomes institutionalized and as the element of novelty fades over time, it then becoming an ordinary reality in the organization. Thus, KT can be considered to be successful if it passes all stages of the KT process properly. Each stage in the KT process can also be seen as the level of the KT process that occurs in the organization. This also indicates that organizational culture is important as an ecosystem where the source and the recipient of knowledge belong.

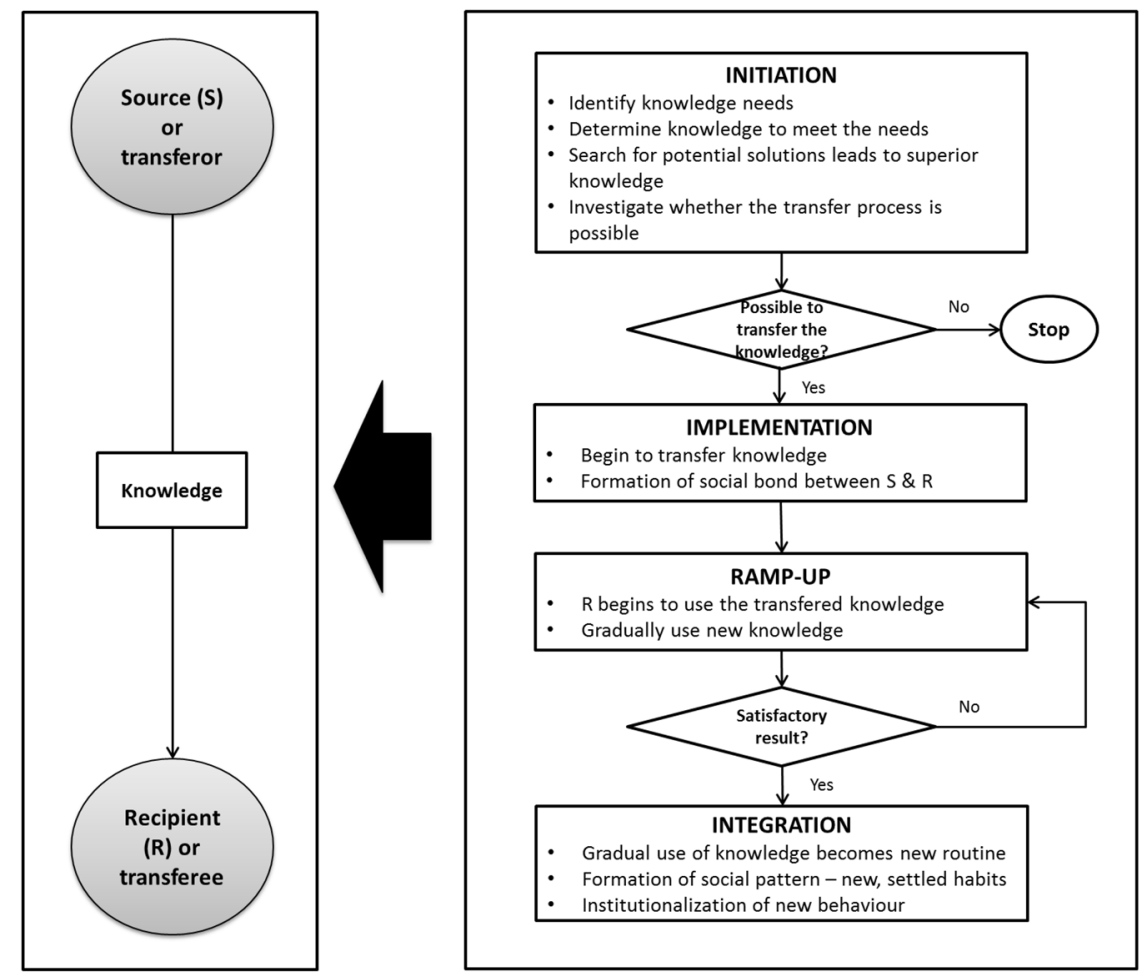

Source: modified from Szulanski $(1996 ; 2003)$

Fig. 2 Knowledge Transfer Process 
The basic and significant aspect in KTR, which is the basis for KT success, is the organizational factor (Raudeliūnienè et al., 2016). This factor is considered to influence the process of knowledge sharing. This readiness dimension points out organizational condition for cross-cultural KT. This organizational readiness includes readiness from the organizational side. Seeing further on (Hsu 2012), vision, and awareness of KT activity, company's culture, work design, RandS, and performance appraisal seem to be important factor for KT. (Fig. 3)These elements influence how the personal selection and the work design of the source and recipient of knowledge may affect the next stage of the process.

\section{Vision and Awareness on Knowledge Transfer}

Management must firstly have awareness and clear vision regarding KT. Then, the management should communicate their vision regarding KT as the knowledge needs to be "nurtured, supported, enhanced, and cared for" and financially supported (Disterer, 2001). The vision of top-level management is fundamentally important for the direction of expatriate use and the basis for creating a supportive environment for conducting KT in an organization. This vision forms a basis for a strategy for RandS and work design applied to expatriates. This vision is certainly based on the awareness about the importance of KT which determines the choice of strategies and tactics to acquire and to master the knowledge from expatriates.

\section{Company's Culture}

Culture is important glue for social interaction (Freiling and Fichtner, 2010). Company's culture is a critical success factor for knowledge sharing which is important for KT (Al-Alawi et al., 2007; Attar, 2020; Rahman et al., 2018). Company's culture

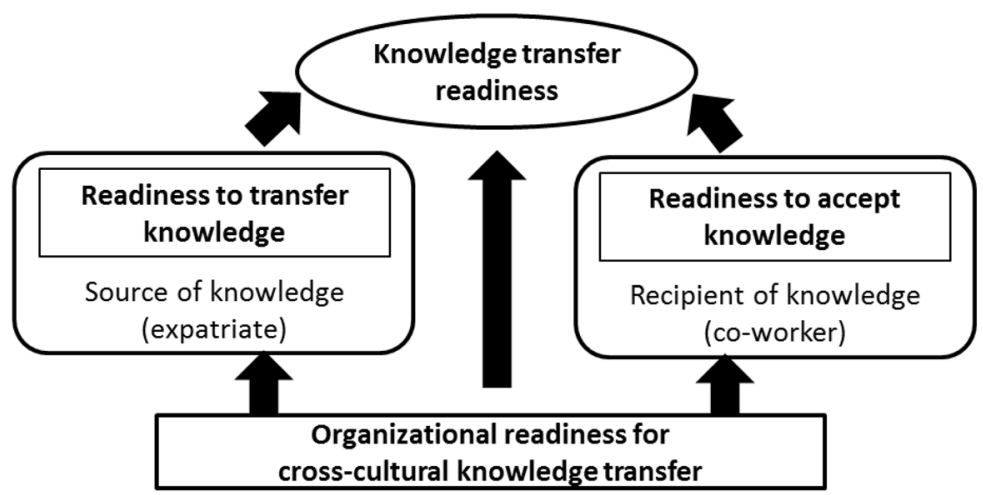

Source: developed by authors

Fig. 3 Knowledge Transfer Readiness Framework 
influences personal perceptions of "knowledge authority" and make preferences for option for knowledge transfer mechanisms (Wei \& Miraglia, 2017). Therefore, an innovative culture in a company can bring perceptions that knowledge authority and the chosen of KT mechanisms are directed to bring value as much as possible to achieve innovation. Innovation culture is the norm of behavior and values that are understood and accepted by all members of the organization and used as a basis for the rules of behavior in the organization to create innovation. In the context of KT, innovation culture remains to be important company's culture due to the underlying motivation as the basis of action during the KT process. The culture can also influence the ultimate goal of the KT process, because it is an enabler for the habit of creative thinking and actively seeking and mastering new knowledge. In addition, it plays an important role in forming a mindset for learning by perceiving the world in new ways.

\section{Work Design}

Job design is important for motivational reasons. (Foss et al., 2009). For specific project for knowledge transfer, job design can be translated into work design which then influence the intrinsic motivation to engage in the knowledge sharing (Karim \& Majid, 2018) as part of KT process. In KT context, work design is a design for the assignment of expatriates. This design includes how the expatriate interacts with local employees as his/her co-workers, the mechanism chosen for the KT, and the supporting activities (e.g. training, assistance) needed to conduct the KT, especially to acquire knowledge from the expatriate. A good work design can create a smooth KT process.

\section{Recruitment and Selection}

As part of expatriation process, RandS is an important stage determining pertinent expatriates to be employed as well as the suppliers of expatriates-in case of the multi-stage RandS. The accuracy in this selection is a determinant factor for KT's success because it determines the accuracy and appropriateness of the source of knowledge and its characteristics in accordance with the company's conditions.

\section{Performance Appraisal}

Performance appraisal in forms of rewards and incentive methods can be an extrinsic motivators for source and recipient of knowledge to share and transfer knowledge (Disterer, 2001). The importance of performance appraisal in KT process is also related to the additional work of local employees, especially those who act as co-workers of expatriates outside their routines. Performance appraisal is also important to encourage local employees to absorb new knowledge more actively, especially from expatriates, to suit both individual and organizational needs. The 
absence or lack of attention to this aspect may cause reluctance of the local employees to perform additional tasks. Thus, the performance appraisal occurs as a reward received for work that has the potential to provide added value to the firm's business activities.

In addition to the organizational readiness dimension, another dimension that forms the KTR is readiness to transfer and to accept knowledge. Readiness to transfer knowledge illustrates an important characteristic that must be possessed by the source of knowledge-in this case expatriate, while readiness to accept knowledge illustrates the same thing but comes from knowledge recipient's side-in this case is the local employee. These dimensions embed in the source and recipient of knowledge, and can be considered as individual characteristics (Oliveira \& Pinheiro, 2020). The characteristics include knowledge base, work habits, absorptive capacity (ACAP), cultural intelligence, openness in knowledge sharing, and communication skill.

\section{Knowledge Base}

Knowledge base can be easily understood as a tacit basic understanding of scientific and practical matters (Busch, 1967). It influences how a person sees a problem and the best solution to overcome the problem. The closer the knowledge base between the source and the recipient of knowledge, the faster the recipient understands the new knowledge from the source is. This can enable better knowledge development as expected in KT.

\section{Work Habits}

Work habits can be defined as assumptions, values and norms repeatedly carried out by employees or developed in the organization, manifested in attitudes into behavior, beliefs, and targets at work, opinions and actions. Differences in work habits between expatriates and local employees (e.g. in the speed of work, work ethic, work standards) can trigger individual conflicts that potentially discourage them to interact. This eventually becomes an obstacle in conducting KT.

\section{Absorptive Capacity (ACAP)}

ACAP determines the acceptance of knowledge and generally defined as the ability to identify, assimilate, and exploit knowledge from the external environment (Cohen \& Levinthal, 1990). (Zahra \& George, 2002) divided ACAP into two categories, namely potential ACAP consisting of knowledge acquisition and assimilation, and realized ACAP which consisted of knowledge transformation and exploitation. Knowledge acquisition is the ability to identify and receive external knowledge, while knowledge assimilation is related to routines and processes that occur in companies that enable testing, interpretation, and understanding the information 
obtained from external sources. Knowledge acquisition can be translated as an individual's ability to identify and receive external knowledge, while knowledge assimilation is related to the routines experienced by the individual in the company. Knowledge transformation represents ability to develop and improve routines that facilitate the combination process, while knowledge exploitation involves routines allowing companies to improve and expand existing knowledge by including it in its operations. Knowledge transformation may occur in form of ability of individuals to develop and improve their routines, while knowledge exploitation involves individual routines to develop existing knowledge by improving tasks or daily work. For expatriate, ACAP is very important to gain understanding about the task and condition of environment where he/she is being employed and take action to create possible solution.

For knowledge recipient, ACAP is very important to obtain understanding about new knowledge from its source, and then adapt the knowledge-if necessary, and implement it in to the routines. This aspect is very important because it becomes the entry point of the early stage, which determined the success of the next stages of the process.

\section{Cultural Intelligence}

The knowledge provider and the recipient from different countries often face cultural barriers. Therefore cultural intelligence remains important. Cultural intelligence can be defined as the capability to effectively carry out functions and manage environments that differ culturally (Ang \& Van Dyne, 2008). This is a quality that must be possessed by both parties in order to overcome cultural barriers in interacting. This kind of intelligence can also prevent anxiety and discomfort in interacting commonly felt by people who are culturally different (Thomas et al., 2008). (Prasada, 2014) also points out that cultural differences become one of the obstacles to KT. By understanding each other's cultural background, knowledge providers and recipients will interact more comfortably so that knowledge distribution can take place more smoothly. During interaction, expatriates and local employees naturally communicate through similar language. In this case, communication skill, either verbal or non-verbal, is very important for transferring knowledge. Foreign language skills, at least passively, by local employees will be very helpful in communicating with expatriates. Whilst, expatriate who can communicate in local employee's language seems to be a better preference, as generally occur in many countries.

\section{Openness in Knowledge Sharing}

Knowledge transmission can be made possible through knowledge sharing. In knowledge sharing, openness is important due to the comprehensiveness of knowledge content needed by each involved party. Openness in knowledge sharing relates with tendency of the source of knowledge to share knowledge with the recipient (Chow et al., 2000). This openness shows honesty on the truth of shared knowledge. 
In this case, sometimes in knowledge sharing there is some knowledge that is not completely disclosed. In addition, sometimes there are parties who provide important knowledge incompletely, and for some reasons they are hidden. This condition certainly affects the success of KT because it is related to the completeness of the knowledge needed by the recipient.

The three dimensions -described earlier as KTR- forms cross-cultural relationship qualities which shows how well the interaction works and formed as mechanism to achieve knowledge transfer quality (KTQ). The relationship quality consists of three aspects: quality of interaction, quality of relations, and quality of cognitive system.

\section{Quality of Interaction}

Interaction shows actual patterns or linkages indicated by the frequency of interactions especially face-to-face interactions. This type of interaction is very important especially for transferring tacit knowledge from expatriate to local employee. This may defines the quality of interactions between them. The higher the frequency of interactions, the more effective the KT process is. Intensive interaction increases the probability to transfer tacit knowledge and also its amount. Quality of interactions is also determined by the depth of interaction, setting the tacitness level of the transferred knowledge which can be obtained from expatriates. At the highest level, the quality of interactions is determined by the effectiveness and efficiency of relations. This can decrease their effort and energy, while the goal of KT still can be achieved successfully. Effective interaction enables effective communication to obtain the targeted knowledge (Kowalska-Styczen et al., 2018). Efficient interaction can enable a recipient to obtain knowledge from knowledge source in minimum time. An efficient interaction can also reduce the use of resources in an organization. Therefore an efficient interaction can considerably increase the overall efficiency in a company (Caballé et al., 2008).

\section{Quality of Relations}

Quality of relations defines the nature of the relationship itself. The quality is determined by trust which can be defined as a person's expectation that his partner will behave generously, not opportunistically, in a relationship (Nahapiet \& Ghoshal, 1998). Since trust increases the motivation of a person to assist his co-worker in gaining new knowledge, it can enable KT (Lane et al., 2001). Furthermore, trust can also encourage an open communication and fair evaluation (Hsu, 2008). Trust can either be grown or vanished as the actors interact within a certain period (Rutter, 2001). Consequently, when the firms arouse more people to reflect and to make decision, employees tend to trust only those who have greatest role for supporting their tasks (Gal \& Gal, 2019). Mutual trust is necessary to create open knowledge sharing environment (Disterer, 2001). Quality of relations is also determined by learning effectiveness which shows the quality of learning especially from local employee as knowledge recipient/receiver. The more effective the relation, the higher the quality will be. Another element defining quality of relations is the formation of feedback seeking behavior (FSB) which represents activities conducted by 
individuals to seek feedback to reduce uncertainty about what goals to pursue and the behaviors required to achieve those goals. This activity also describes how an individual seek feedback about how their behaviors are being evaluated by others in order to achieve a sense of competency (VandeWalle, 2003). The presence of this behavior in KT activities may pursue successful learning process.

\section{Quality of Cognitive System}

Quality of cognitive system describes representation, interpretation and shared systems from the provider and recipient of knowledge (Cicourel, 1973). This cognitive dimension is represented by a shared vision that supports shared understanding of collective goals and the right steps to behave in a social system (Tsai \& Ghoshal, 1998). Shared vision is an important cognitive element underlying social relations that affect KT (Inkpen \& Tsang, 2005). A group of individuals who have a shared vision may have a better understanding for each other so they can form stronger social ties. Ownership of a shared vision is certainly a challenge in the process of KT from expatriate to local employee, because both parties have different values and beliefs (Oddou et al., 2009). The collective goals of both parties should also align with company's purpose to employ the expatriate. This dimension is also represented by similarity of epistemic principles describing the distance in understanding the knowledge base from both parties. This aspect is important because its formation will strengthen the shared vision and accelerate the accomplishment of collective goals.

Relationship qualities are formed by interrelationship between dimensions and variables of KTR which determines the result of KT process whether it is success or fail. The level of success or failure can be varied according to three aspects defining its KTQ, consisting three aspects:

a) Accuracy of the transferred knowledge (knowledge accuracy). KT is expected to transfer the 'right' knowledge as needed by local firms, via local employees and have potential to create spin-off (Del Giudice et al., 2013). Therefore, local employee must absorb particular knowledge based on the needs. Knowledge transfer must enable absorption of specific knowledge from expatriate to local employee in appropriation with knowledge that is needed by the firm. This shows that the accuracy of the transferred knowledge define quality of knowledge transfer. In this case, the exactness of the transferred knowledge to the needs of the firm is highly required. The more the knowledge meet firm's need, the better the quality of the KT is.

b) Amount of the transferred knowledge (amount of knowledge). To be able to be used in a firm, the transferred knowledge should reach a certain level of adequacy. This indicates that the amount of the transferred knowledge should be sufficient to be used by local employee. The more amount of the transferred knowledge, the higher the quality of knowledge transfer will be. In the KT process, the transferred knowledge usually includes also 'residual' knowledge or unimportant knowledge. Therefore, the assessment of KTQ should combine the accuracy and the amount of the transferred knowledge, which shows the effectiveness to obtain 'the right' knowledge on the right amount. 
c) Depth of understanding (of the recipient). To be able to implement the new knowledge, the recipient of knowledge - the local employee, in this case - should have good understanding about the knowledge by completely comprehend the situation in which problem occur in the firm. This indicates that the depth of understanding is important and particular level of sufficiency should be achieved in knowledge transfer. The deeper the understanding, the better the quality of the knowledge transfer is.

\section{Methodology}

This research pragmatically combined grounded theory (Strauss \& Corbin, 1994) and multiple case studies (Yin, 2003). Yin's case study was used to answer 'how' and 'why' elements in the KTR were important, and 'why' they were important. Manual thematic analysis was conducted by which themes and codes were developed based on the issue of different groups of elements needed to achieve different levels of KTQ and types of technological capability. Grounded theory was used to explore and explain the pattern of KTQ achievement for different conditions of KTR. Three phases of coding was conducted (Charmaz, 2006) in complement with (Maxwell's, 2005, 2012) strategy which included categorizing, connecting, and displays strategies. Overall, the analysis was also focused on the presence of elements and their levels in each dimension of KTR to observe their patterns or tendencies by grouping similar cases and comparing different cases.

The research stage is briefly shown in Fig. 4. The assessment criteria for KTR's and relationship qualities' elements for each dimension of KTQ are shown in the Tables 1,2 and 3. The operational definition of production and innovation capability is

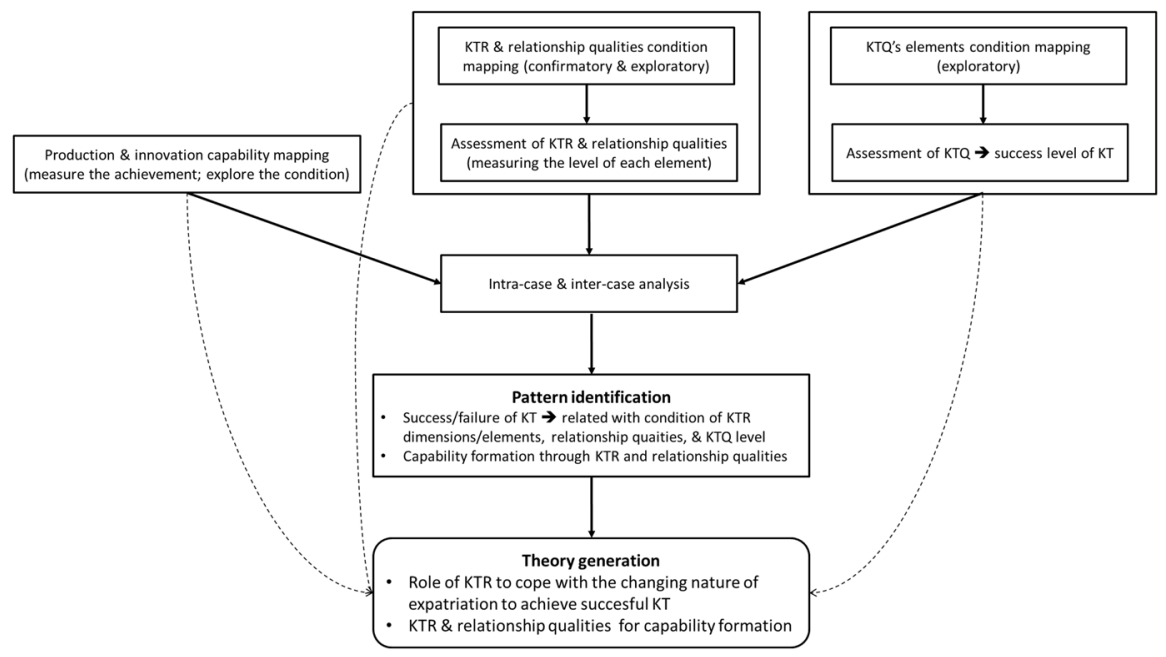

Source: developed by authors

Fig. 4 Research stages 
Table 1 Assessment criteria for KTR's and relationship qualities' elements

\begin{tabular}{|c|c|c|c|c|}
\hline \multirow[t]{2}{*}{ Dimension } & \multirow[t]{2}{*}{ Variabel } & \multicolumn{3}{|l|}{ Level } \\
\hline & & Good & Fair & Poor/low \\
\hline \multirow[t]{4}{*}{$\begin{array}{l}\text { Readiness to } \\
\text { Transfer }\end{array}$} & $\begin{array}{l}\text { Cultural } \\
\text { intelligence } \\
\text { (Ang \& Van } \\
\text { Dyne, 2008; } \\
\text { Prasada, } \\
\text { 2014) }\end{array}$ & $\begin{array}{l}\text { expatriate is able } \\
\text { to carry out } \\
\text { functions and } \\
\text { manage envi- } \\
\text { ronment that } \\
\text { differ cultur- } \\
\text { ally effectively } \\
\text { (related with } \\
\text { language/ } \\
\text { communica- } \\
\text { tion skill and } \\
\text { adaptation to } \\
\text { local culture) }\end{array}$ & $\begin{array}{l}\text { expatriate is } \\
\text { able to carry } \\
\text { out functions } \\
\text { and manage } \\
\text { environment } \\
\text { that differ } \\
\text { culturally quite } \\
\text { effectively }\end{array}$ & $\begin{array}{l}\text { expatriate is disable to carry out } \\
\text { functions and manage envi- } \\
\text { ronment that differ culturally } \\
\text { effectively }\end{array}$ \\
\hline & $\begin{array}{l}\text { Work habits } \\
(\mathrm{Hsu}, 2008)\end{array}$ & $\begin{array}{l}\text { expatriate's atti- } \\
\text { tude is aligned } \\
\text { (proactive) and } \\
\text { adapted with } \\
\text { the attitude of } \\
\text { local employ- } \\
\text { ees }\end{array}$ & $\begin{array}{l}\text { expatriate's } \\
\text { attitude is } \\
\text { alligned (quite } \\
\text { proactive) and } \\
\text { adapted with } \\
\text { the attitude } \\
\text { of local } \\
\text { employees, } \\
\text { but still trigger } \\
\text { small conflicts } \\
\text { or create } \\
\text { reluctance to } \\
\text { interact }\end{array}$ & $\begin{array}{l}\text { expatriate's attitude is not alligned } \\
\text { (passive) and not adapted with } \\
\text { the attitude of local employees; } \\
\text { the attitude trigger conflicts or } \\
\text { create unwillingness to interact }\end{array}$ \\
\hline & $\begin{array}{l}\text { ACAP (Cohen } \\
\text { \& Levinthal, } \\
\text { 1990; Zahra } \\
\text { \& George, } \\
\text { 2002) }\end{array}$ & $\begin{array}{l}\text { expatriate is able } \\
\text { to identify, } \\
\text { assimilate, } \\
\text { and exploit } \\
\text { all important } \\
\text { knowledge } \\
\text { from co- } \\
\text { worker and } \\
\text { other sources } \\
\text { from the local } \\
\text { company }\end{array}$ & $\begin{array}{l}\text { expatriate is able } \\
\text { to identify, } \\
\text { assimilate, and } \\
\text { exploit only } \\
\text { limited amount } \\
\text { of important } \\
\text { knowledge } \\
\text { (but still suf- } \\
\text { ficient) from } \\
\text { co-worker and } \\
\text { other sources } \\
\text { from the local } \\
\text { company }\end{array}$ & $\begin{array}{l}\text { expatriate is not able to identify, } \\
\text { assimilate, and exploit important } \\
\text { knowledge from co-worker and } \\
\text { other sources from the local } \\
\text { company, or able to identify, } \\
\text { assimilate, and exploit not much } \\
\text { important knowledge (still insuf- } \\
\text { ficient) }\end{array}$ \\
\hline & $\begin{array}{l}\text { Knowledge } \\
\text { base (Busch, } \\
1967 \text { ) }\end{array}$ & $\begin{array}{l}\text { expatriate can } \\
\text { understand all } \\
\text { scientific and } \\
\text { practical mat- } \\
\text { ters occurred } \\
\text { during assign- } \\
\text { ment }\end{array}$ & $\begin{array}{l}\text { expatriate } \\
\text { can only } \\
\text { understand } \\
\text { the crucial } \\
\text { scientific and } \\
\text { practical mat- } \\
\text { ters occurred } \\
\text { during assign- } \\
\text { ment }\end{array}$ & $\begin{array}{l}\text { expatriate cannot understand any } \\
\text { scientific and practical matters } \\
\text { occurred during assignment or } \\
\text { can understand only a little but } \\
\text { still insufficient }\end{array}$ \\
\hline
\end{tabular}


Table 1 (continued)

\begin{tabular}{|c|c|c|c|c|}
\hline \multirow[t]{2}{*}{ Dimension } & \multirow[t]{2}{*}{ Variabel } & \multicolumn{3}{|l|}{ Level } \\
\hline & & Good & Fair & Poor/low \\
\hline & $\begin{array}{l}\text { Openness in } \\
\text { knowledge } \\
\text { sharing } \\
\text { (Chow, } \\
\text { Deng \& Ho, } \\
\text { 2000) }\end{array}$ & $\begin{array}{l}\text { expatriate } \\
\text { disclose all } \\
\text { important } \\
\text { knowledge to } \\
\text { local employee }\end{array}$ & $\begin{array}{l}\text { expatriate does } \\
\text { not disclose } \\
\text { all important } \\
\text { knowledge to } \\
\text { local employee } \\
\text { (some knowl- } \\
\text { edge is not } \\
\text { completely } \\
\text { disclosed, but } \\
\text { still sufficient } \\
\text { to achieve the } \\
\text { KT purpose) }\end{array}$ & $\begin{array}{l}\text { expatriate only disclose little } \\
\text { important knowledge to local } \\
\text { employee (or even no knowledge } \\
\text { is disclosed) }\end{array}$ \\
\hline \multirow[t]{3}{*}{$\begin{array}{l}\text { Readiness to } \\
\text { Accept }\end{array}$} & $\begin{array}{l}\text { Cultural } \\
\text { intelligence } \\
\text { (Ang \& Van } \\
\text { Dyne, 2008; } \\
\text { Prasada, } \\
\text { 2014) }\end{array}$ & $\begin{array}{l}\text { local employee } \\
\text { is able to carry } \\
\text { out functions } \\
\text { and manage } \\
\text { environment } \\
\text { that differ } \\
\text { culturally } \\
\text { effectively } \\
\text { (related with } \\
\text { language and } \\
\text { local culture) }\end{array}$ & $\begin{array}{l}\text { local employee } \\
\text { is able to carry } \\
\text { out functions } \\
\text { and manage } \\
\text { environment } \\
\text { that differ } \\
\text { culturally quite } \\
\text { effectively }\end{array}$ & $\begin{array}{l}\text { local employee is disable to } \\
\text { carry out functions and manage } \\
\text { environment that differ culturally } \\
\text { effectively }\end{array}$ \\
\hline & $\begin{array}{l}\text { Work habits } \\
\text { (Hsu, 2008) }\end{array}$ & $\begin{array}{l}\text { local employee's } \\
\text { attitude is } \\
\text { alligned } \\
\text { (proactive) and } \\
\text { adapted with } \\
\text { the attitude of } \\
\text { expatriate }\end{array}$ & $\begin{array}{l}\text { local employee's } \\
\text { attitude is } \\
\text { alligned (quite } \\
\text { proactive) and } \\
\text { adapted with } \\
\text { the attitude of } \\
\text { expatriate, but } \\
\text { still trigger } \\
\text { small conflicts } \\
\text { or create } \\
\text { reluctance to } \\
\text { interact }\end{array}$ & $\begin{array}{l}\text { local employee's attitude is not } \\
\text { aligned (passive) and not adapted } \\
\text { with the attitude of expatriate; } \\
\text { the attitude trigger conflicts or } \\
\text { create unwillingness to interact }\end{array}$ \\
\hline & $\begin{array}{l}\text { ACAP (Cohen } \\
\text { and } \\
\text { Levinthal, } \\
\text { 1990; } \\
\text { Zahra \& } \\
\text { George, } \\
\text { 2002) }\end{array}$ & $\begin{array}{l}\text { local employee } \\
\text { is able to iden- } \\
\text { tify, assimilate, } \\
\text { and exploit } \\
\text { all important } \\
\text { knowledge } \\
\text { from expatri- } \\
\text { ate and other } \\
\text { important } \\
\text { sources }\end{array}$ & $\begin{array}{l}\text { local employee } \\
\text { is able to } \\
\text { identify, } \\
\text { assimilate, and } \\
\text { exploit only } \\
\text { limited amount } \\
\text { of important } \\
\text { knowledge } \\
\text { (but still suf- } \\
\text { ficient) from } \\
\text { co-worker and } \\
\text { other impor- } \\
\text { tant sources }\end{array}$ & $\begin{array}{l}\text { local employee is not able to } \\
\text { identify, assimilate, and exploit } \\
\text { important knowledge from expa- } \\
\text { triate and other sources from } \\
\text { the local company, or able to } \\
\text { identify, assimilate, and exploit } \\
\text { not much important knowledge } \\
\text { (still insufficient) }\end{array}$ \\
\hline
\end{tabular}


Table 1 (continued)

\begin{tabular}{|c|c|c|c|c|}
\hline \multirow[t]{2}{*}{ Dimension } & \multirow[t]{2}{*}{ Variabel } & \multicolumn{3}{|l|}{ Level } \\
\hline & & Good & Fair & Poor/low \\
\hline & $\begin{array}{l}\text { Knowledge } \\
\text { base (Busch, } \\
\text { 1967) }\end{array}$ & $\begin{array}{l}\text { local employee } \\
\text { can understand } \\
\text { all scientific } \\
\text { and practi- } \\
\text { cal matters } \\
\text { occurred dur- } \\
\text { ing assignment }\end{array}$ & $\begin{array}{l}\text { local employee } \\
\text { can only } \\
\text { understand } \\
\text { the crucial } \\
\text { scientific and } \\
\text { practical mat- } \\
\text { ters occurred } \\
\text { during assign- } \\
\text { ment }\end{array}$ & $\begin{array}{l}\text { local employee cannot understand } \\
\text { any scientific and practical mat- } \\
\text { ters occurred during assignment } \\
\text { or can understand only a little } \\
\text { but still insufficient }\end{array}$ \\
\hline \multirow[t]{2}{*}{$\begin{array}{l}\text { Organi- } \\
\text { zational } \\
\text { Readiness }\end{array}$} & $\begin{array}{l}\text { Vision and } \\
\text { awareness on } \\
\text { KT (Disterer, } \\
\text { 2001) }\end{array}$ & $\begin{array}{l}\text { top-level man- } \\
\text { agement has } \\
\text { clear vision } \\
\text { and high } \\
\text { awareness } \\
\text { about the } \\
\text { importance of } \\
\text { KT, and well- } \\
\text { implemented } \\
\text { in strategy/tac- } \\
\text { tics for KT }\end{array}$ & $\begin{array}{l}\text { : top-level } \\
\text { management } \\
\text { has quite clear } \\
\text { vision and } \\
\text { quite high } \\
\text { awareness } \\
\text { about the } \\
\text { importance } \\
\text { of KT, and } \\
\text { quite well } \\
\text { implemented } \\
\text { in strategy/ } \\
\text { tactics for KT } \\
\text { (or unexcel- } \\
\text { lent condition } \\
\text { related with } \\
\text { vision and } \\
\text { awareness, but } \\
\text { still sufficient } \\
\text { for conducting } \\
\text { KT) }\end{array}$ & $\begin{array}{l}\text { top-level management has no clear } \\
\text { vision and/or has low awareness } \\
\text { about the importance of KT, and } \\
\text { implemented in strategy/tactics } \\
\text { for KT }\end{array}$ \\
\hline & $\begin{array}{l}\text { Company’s } \\
\text { culture (Al- } \\
\text { Alawi et } \\
\text { al., 2007; } \\
\text { Attar, 2020; } \\
\text { Rahman } \\
\text { et al., 2018; } \\
\text { Wei \& Mira- } \\
\text { glia, 2017) }\end{array}$ & $\begin{array}{l}\text { culture in the } \\
\text { local company } \\
\text { can enable the } \\
\text { habit of crea- } \\
\text { tive thinking, } \\
\text { and actively } \\
\text { seek and } \\
\text { mastering new } \\
\text { knowledge }\end{array}$ & $\begin{array}{l}\text { culture in the } \\
\text { local company } \\
\text { can enable the } \\
\text { habit of crea- } \\
\text { tive thinking, } \\
\text { and actively } \\
\text { seek and } \\
\text { mastering new } \\
\text { knowledge, but } \\
\text { there are still } \\
\text { obstacles for } \\
\text { the achieve- } \\
\text { ment }\end{array}$ & $\begin{array}{l}\text { culture in the local company can- } \\
\text { not enable the habit of creative } \\
\text { thinking, and actively seek and } \\
\text { mastering new knowledge }\end{array}$ \\
\hline
\end{tabular}


Table 1 (continued)

\begin{tabular}{|c|c|c|c|c|}
\hline \multirow[t]{2}{*}{ Dimension } & \multirow[t]{2}{*}{ Variabel } & \multicolumn{3}{|l|}{ Level } \\
\hline & & Good & Fair & Poor/low \\
\hline & $\begin{array}{l}\text { Work design } \\
\text { (Foss et al., } \\
\text { 2009; } \\
\text { Karim \& } \\
\text { Majid, 2018) }\end{array}$ & $\begin{array}{l}\text { local company } \\
\text { has a complete } \\
\text { design in how } \\
\text { expatriate } \\
\text { can interact } \\
\text { effectively } \\
\text { with local } \\
\text { employee, } \\
\text { including the } \\
\text { mechanism } \\
\text { chosen and } \\
\text { the supporting } \\
\text { activities to } \\
\text { acquire knowl- } \\
\text { edge from the } \\
\text { expatriate }\end{array}$ & $\begin{array}{l}\text { local company } \\
\text { has an incom- } \\
\text { plete design } \\
\text { (but still } \\
\text { effective) in } \\
\text { how expatriate } \\
\text { can interact } \\
\text { effectively } \\
\text { with local } \\
\text { employee, } \\
\text { including the } \\
\text { mechanism } \\
\text { chosen and } \\
\text { the supporting } \\
\text { activities to } \\
\text { acquire knowl- } \\
\text { edge from the } \\
\text { expatriate }\end{array}$ & $\begin{array}{l}\text { local company has incomplete } \\
\text { or even has no design in how } \\
\text { expatriate can interact effectively } \\
\text { with local employee, including } \\
\text { the mechanism chosen and the } \\
\text { supporting activities to acquire } \\
\text { knowledge from the expatriate }\end{array}$ \\
\hline & $\begin{array}{l}\text { Recruitment } \\
\text { and selection } \\
\text { (Prihadyanti } \\
\text { et al., 2019) }\end{array}$ & $\begin{array}{l}\text { the local } \\
\text { company have } \\
\text { RandS of } \\
\text { expatriate who } \\
\text { is match with } \\
\text { company's } \\
\text { needs, or only } \\
\text { 'optimum' } \\
\text { one but the } \\
\text { company can } \\
\text { prepare the } \\
\text { suitable co- } \\
\text { worker from } \\
\text { local employee }\end{array}$ & $\begin{array}{l}\text { the local } \\
\text { company } \\
\text { have RandS } \\
\text { of expatriate } \\
\text { who is quite } \\
\text { match with } \\
\text { company's } \\
\text { needs, or only } \\
\text { 'optimum' } \\
\text { one but the } \\
\text { company can } \\
\text { prepare co- } \\
\text { worker from } \\
\text { local employee } \\
\text { with sufficient } \\
\text { characteristics }\end{array}$ & $\begin{array}{l}\text { the local company have insufficient } \\
\text { RandS for expatriate or cannot } \\
\text { prepare the suitable co-worker } \\
\text { from local employee }\end{array}$ \\
\hline
\end{tabular}


Table 1 (continued)

\begin{tabular}{|c|c|c|c|c|}
\hline \multirow[t]{2}{*}{ Dimension } & \multirow[t]{2}{*}{ Variabel } & \multicolumn{3}{|l|}{ Level } \\
\hline & & Good & Fair & Poor/low \\
\hline & $\begin{array}{l}\text { Performance } \\
\text { appraisal } \\
\text { (Disterer, } \\
\text { 2001) }\end{array}$ & $\begin{array}{l}\text { local com- } \\
\text { pany has an } \\
\text { excellent } \\
\text { performance } \\
\text { management } \\
\text { with appropri- } \\
\text { ate merit (or } \\
\text { appraisal) } \\
\text { system espe- } \\
\text { cially for local } \\
\text { employee who } \\
\text { is assigned } \\
\text { as co-worker } \\
\text { of expatriate; } \\
\text { the system } \\
\text { can encourage } \\
\text { and satisfy } \\
\text { the co-worker } \\
\text { to actively } \\
\text { absorb new } \\
\text { knowledge } \\
\text { from expatriate }\end{array}$ & $\begin{array}{l}\text { local company } \\
\text { has an quite } \\
\text { excellent } \\
\text { performance } \\
\text { management } \\
\text { with appropri- } \\
\text { ate merit (or } \\
\text { appraisal) } \\
\text { system espe- } \\
\text { cially for local } \\
\text { employee who } \\
\text { is assigned as } \\
\text { co-worker of } \\
\text { expatriate; the } \\
\text { system cannot } \\
\text { fully encour- } \\
\text { age and satisfy } \\
\text { the co-worker } \\
\text { to actively } \\
\text { absorb new } \\
\text { knowledge } \\
\text { from expatriate }\end{array}$ & $\begin{array}{l}\text { local company has no performance } \\
\text { management with appropriate } \\
\text { merit (or appraisal) system espe- } \\
\text { cially for local employee who is } \\
\text { assigned as co-worker of expatri- } \\
\text { ate; the system the co-worker } \\
\text { feel reluctant to actively absorb } \\
\text { new knowledge from expatriate }\end{array}$ \\
\hline \multirow[t]{2}{*}{$\begin{array}{l}\text { Relationship } \\
\text { Qualities: } \\
\text { Quality of } \\
\text { interac- } \\
\text { tion }\end{array}$} & $\begin{array}{c}\text { Frequency of } \\
\text { interaction }\end{array}$ & $\begin{array}{l}\text { expatriate and } \\
\text { local employee } \\
\text { has very } \\
\text { intense interac- } \\
\text { tion (daily, and } \\
\text { often all day) }\end{array}$ & $\begin{array}{l}\text { expatriate and } \\
\text { local employee } \\
\text { has quite } \\
\text { intense interac- } \\
\text { tion (not meet- } \\
\text { ing everyday, } \\
\text { but more than } \\
3 \text { times a week } \\
\text { for all day, or } \\
\text { only meet face } \\
\text { to face when } \\
\text { needed but in } \\
\text { a very intense } \\
\text { interaction) }\end{array}$ & $\begin{array}{l}\text { expatriate and local employee has } \\
\text { unintense interaction }\end{array}$ \\
\hline & $\begin{array}{l}\text { Depth of inter- } \\
\text { action }\end{array}$ & $\begin{array}{l}\text { interaction can } \\
\text { transfer tacit } \\
\text { and explicit } \\
\text { knowledge } \\
\text { from expatri- } \\
\text { ate to local } \\
\text { employee }\end{array}$ & $\begin{array}{l}\text { interaction can } \\
\text { transfer tacit } \\
\text { and/or explicit } \\
\text { knowledge } \\
\text { from expatri- } \\
\text { ate to local } \\
\text { employee } \\
\text { although } \\
\text { imperfect (but } \\
\text { still sufficient } \\
\text { to achieve the } \\
\text { purpose of } \\
\text { KT) }\end{array}$ & $\begin{array}{l}\text { interaction cannot transfer tacit } \\
\text { and/or explicit knowledge from } \\
\text { expatriate to local employee (or } \\
\text { very little and insufficient to } \\
\text { achieve the purpose of KT) }\end{array}$ \\
\hline
\end{tabular}


Table 1 (continued)

\begin{tabular}{|c|c|c|c|c|}
\hline \multirow[t]{2}{*}{ Dimension } & \multirow[t]{2}{*}{ Variabel } & \multicolumn{3}{|l|}{ Level } \\
\hline & & Good & Fair & Poor/low \\
\hline & $\begin{array}{l}\text { Effectiveness } \\
\text { of interaction } \\
\text { (Kowalska- } \\
\text { Styczen, } \\
\text { Malarz, \& } \\
\text { Paradowski, } \\
\text { 2018) }\end{array}$ & $\begin{array}{l}\text { interaction } \\
\text { between } \\
\text { expatriate and } \\
\text { local employee } \\
\text { can meet the } \\
\text { predefined } \\
\text { target for KT }\end{array}$ & $\begin{array}{l}\text { interaction } \\
\text { between expa- } \\
\text { triate and local } \\
\text { employee can } \\
\text { meet almost } \\
\text { all predefined } \\
\text { target for KT } \\
\text { (still sufficient } \\
\text { to achieve pur- } \\
\text { pose of KT) }\end{array}$ & $\begin{array}{l}\text { interaction between expatriate and } \\
\text { local employee cannot meet the } \\
\text { predefined target for KT }\end{array}$ \\
\hline & $\begin{array}{l}\text { Efficiency of } \\
\text { interaction } \\
\text { (Caballé } \\
\text { et al., 2008) }\end{array}$ & $\begin{array}{l}\text { interaction } \\
\text { between expa- } \\
\text { triate and local } \\
\text { employee use } \\
\text { very minimum } \\
\text { time and finan- } \\
\text { cial resource } \\
\text { (less than the } \\
\text { allocated time } \\
\text { and budget) }\end{array}$ & $\begin{array}{l}\text { interaction } \\
\text { between } \\
\text { expatriate and } \\
\text { local employee } \\
\text { use the same } \\
\text { amount (or } \\
\text { more but still } \\
\text { be tolerated) of } \\
\text { allocated time } \\
\text { and/or finan- } \\
\text { cial resource }\end{array}$ & $\begin{array}{l}\text { interaction between expatriate } \\
\text { and local employee consume } \\
\text { longer time and higher financial } \\
\text { resource than the allocated ones }\end{array}$ \\
\hline \multirow[t]{2}{*}{$\begin{array}{l}\text { Quality of } \\
\text { relations }\end{array}$} & $\begin{array}{l}\text { Trust (Lane } \\
\text { et al., 2001; } \\
\text { Nahapiet \& } \\
\text { Ghoshal, } \\
\text { 1998) }\end{array}$ & $\begin{array}{l}\text { expatriate and } \\
\text { local employee } \\
\text { are believing } \\
\text { each other, that } \\
\text { each parties } \\
\text { have ability } \\
\text { regarding } \\
\text { his work and } \\
\text { will behave } \\
\text { generously } \\
\text { during their } \\
\text { interaction for } \\
\text { transferring } \\
\text { knowledge }\end{array}$ & $\begin{array}{l}\text { expatriate and } \\
\text { local employee } \\
\text { are not fully } \\
\text { believing each } \\
\text { other, that } \\
\text { each parties } \\
\text { have ability } \\
\text { regarding } \\
\text { his work and } \\
\text { will behave } \\
\text { generously } \\
\text { during their } \\
\text { interaction for } \\
\text { transferring } \\
\text { knowledge }\end{array}$ & $\begin{array}{l}\text { expatriate and local employee are } \\
\text { not believing each other, that } \\
\text { each parties have ability regard- } \\
\text { ing his work and will behave } \\
\text { generously during their interac- } \\
\text { tion for transferring knowledge }\end{array}$ \\
\hline & $\begin{array}{l}\text { Learning effec- } \\
\text { tiveness }\end{array}$ & $\begin{array}{l}\text { interaction } \\
\text { between expa- } \\
\text { triate and local } \\
\text { employee can } \\
\text { create learning } \\
\text { process that } \\
\text { facilitate excel- } \\
\text { lent mastery of } \\
\text { the predefined } \\
\text { knowledge for } \\
\text { local employee }\end{array}$ & $\begin{array}{l}\text { interaction } \\
\text { between expa- } \\
\text { triate and local } \\
\text { employee can } \\
\text { create learn- } \\
\text { ing process } \\
\text { that facilitate } \\
\text { sufficient } \\
\text { mastery of } \\
\text { the predefined } \\
\text { knowledge for } \\
\text { local employee }\end{array}$ & $\begin{array}{l}\text { interaction between expatriate and } \\
\text { local employee cannot create } \\
\text { learning process that facili- } \\
\text { tate sufficient mastery of the } \\
\text { predefined knowledge for local } \\
\text { employee or only create learning } \\
\text { process with low level of mas- } \\
\text { tery of the predefined knowledge }\end{array}$ \\
\hline
\end{tabular}


Table 1 (continued)

\begin{tabular}{|c|c|c|c|c|}
\hline \multirow[t]{2}{*}{ Dimension } & \multirow[t]{2}{*}{ Variabel } & \multicolumn{3}{|l|}{ Level } \\
\hline & & Good & Fair & Poor/low \\
\hline & $\begin{array}{l}\text { Feedback-seek- } \\
\text { ing behavior } \\
\text { (VandeWalle, } \\
\text { 2003) }\end{array}$ & $\begin{array}{l}\text { both expatri- } \\
\text { ate and local } \\
\text { employee } \\
\text { are actively } \\
\text { seeking for } \\
\text { feedback to } \\
\text { achieve prede- } \\
\text { fined goals }\end{array}$ & $\begin{array}{l}\text { only expatri- } \\
\text { ate or local } \\
\text { employee who } \\
\text { is actively } \\
\text { seeking for } \\
\text { feedback } \\
\text { to achieve } \\
\text { predefined } \\
\text { goals, or both } \\
\text { are seeking } \\
\text { for feedback } \\
\text { but not very } \\
\text { active; but the } \\
\text { condition is } \\
\text { still sufficient } \\
\text { for enabling } \\
\text { KT }\end{array}$ & $\begin{array}{l}\text { both expatriate and local employee } \\
\text { are passive }\end{array}$ \\
\hline \multirow[t]{2}{*}{$\begin{array}{l}\text { Quality of } \\
\text { cognitive } \\
\text { system }\end{array}$} & $\begin{array}{l}\text { Shared vision } \\
\text { (Tsai \& } \\
\text { Ghoshal, } \\
\text { 1998; } \\
\text { Inkpen \& } \\
\text { Tsang, 2005) }\end{array}$ & $\begin{array}{l}\text { goal of KT is } \\
\text { understood } \\
\text { by all related } \\
\text { actors (who } \\
\text { have direct } \\
\text { and indirect } \\
\text { involvement in } \\
\text { KT) }\end{array}$ & $\begin{array}{l}\text { goal of KT is } \\
\text { understood by } \\
\text { only crucial } \\
\text { related actors } \\
\text { who directly } \\
\text { and indirectly } \\
\text { involved in } \\
\text { KT or only by } \\
\text { the directly } \\
\text { involved actors }\end{array}$ & $\begin{array}{l}\text { goal of KT is not understood by } \\
\text { the directly involved actors }\end{array}$ \\
\hline & $\begin{array}{l}\text { Similarity of } \\
\text { epistemic } \\
\text { principle } \\
\text { (Oddou } \\
\text { et al., 2009) }\end{array}$ & $\begin{array}{l}\text { the understand- } \\
\text { ing of the } \\
\text { knowledge } \\
\text { base is similar } \\
\text { for expatri- } \\
\text { ate and local } \\
\text { employee }\end{array}$ & $\begin{array}{l}\text { the understand- } \\
\text { ing of the } \\
\text { knowledge } \\
\text { base is quite } \\
\text { similar or } \\
\text { only slightly } \\
\text { different for } \\
\text { expatriate and } \\
\text { local employee } \\
\text { (not causing } \\
\text { conflict) }\end{array}$ & $\begin{array}{l}\text { the understanding of the knowl- } \\
\text { edge base is different for expatri- } \\
\text { ate and local employee (may } \\
\text { cause conflict) }\end{array}$ \\
\hline
\end{tabular}

Source: developed and adapted from various literatures by authors

shown in Table 4. In defining the level of the KTQ, the measurement of the KTQ's elements in terms of amount and accuracy of knowledge were combined because the only value considered was the amount of the 'right' knowledge. For group of expatriates, the considered knowledge transferred was collective knowledge, not individual knowledge. Data collection was conducted through semi-structured interviews and secondary sources (reports, records, or other documents related to KT activities in the company). The selection of local companies as the object of the case studies was based on opportunistic principles taking into account the willingness 
Table 2 Assessment criteria for KTQ's dimensions

\begin{tabular}{|c|c|c|}
\hline Dimension & Level & Qualitative assessment criteria \\
\hline \multirow[t]{3}{*}{$\begin{array}{l}\text { Accuracy of } \\
\text { knowledge }\end{array}$} & Good & $\begin{array}{l}\text { the transferred knowledge is 'accurate' or 'very accurate', the 'right' } \\
\text { knowledge can be transferred }\end{array}$ \\
\hline & Fair & $\begin{array}{l}\text { accurate in only in 'general' knowledge, not very accurate for 'specific' } \\
\text { knowledge }\end{array}$ \\
\hline & Poor & inaccurate for either 'general' or 'specific' knowledge \\
\hline \multirow[t]{3}{*}{$\begin{array}{l}\text { Amount of } \\
\text { knowledge }\end{array}$} & Good & $\begin{array}{l}\text { More than sufficient amount of knowledge that can be obtained from expa- } \\
\text { triate (not distinguished between the 'right' / targeted knowledge and the } \\
\text { 'wrong' / beyond the targeted knowledge) }\end{array}$ \\
\hline & Fair & $\begin{array}{l}\text { Sufficient amount of knowledge that can be obtained from expatriate (not } \\
\text { distinguished between the 'right' / targeted knowledge and the 'wrong' / } \\
\text { beyond the targeted knowledge) }\end{array}$ \\
\hline & Poor & $\begin{array}{l}\text { Very little/ no amount of knowledge that can be obtained from expatri- } \\
\text { ate (not distinguished between the 'right' / targeted knowledge and the } \\
\text { 'wrong' / beyond the targeted knowledge) }\end{array}$ \\
\hline \multirow[t]{3}{*}{$\begin{array}{l}\text { Depth of under- } \\
\text { standing }\end{array}$} & $\begin{array}{r}\text { Good/ } \\
\text { high }\end{array}$ & deep understanding of the transferred knowledge \\
\hline & $\begin{array}{l}\text { Fair / } \\
\text { medium }\end{array}$ & Sufficient understanding but inappropriate \\
\hline & Poor / low & Low / insufficient understanding \\
\hline
\end{tabular}

Source: developed by authors

and openness of the companies, because the topic related to expatriate was considered sensitive by companies in Indonesia. The expatriates were selected only those who had expertise in engineering as their area of knowledge base. The respondents interviewed for each company were varied, but in principle the selection was based on the consideration to the knowledge and experience, and the involvement of the respondents in the KT process. The respondents included expatriate, local employees who were assigned as the expatriate's partners, project managers, and head and/ or staff of human resource departments. Interview questions were semi-structured, to confirm the presence and to explore the condition of KTR elements, KTQ dimensions, relationship qualities, and achievement of the operational and innovation capability. Fig. 4

Table 3 Level of KTQ based on the assessment of its dimensions

\begin{tabular}{|c|c|c|c|c|}
\hline \multirow{2}{*}{\multicolumn{2}{|c|}{$\begin{array}{l}\text { Knowledge Transfer Quality } \\
\text { (KTQ) }\end{array}$}} & \multicolumn{3}{|c|}{ Amount and accuracy of knowledge } \\
\hline & & $\begin{array}{l}\text { Level } 1 \text { (all expected } \\
\text { knowledge can be } \\
\text { obtained by local } \\
\text { employee) }\end{array}$ & $\begin{array}{l}\text { Level } 2 \text { (only a part } \\
\text { of knowledge can } \\
\text { be obtained by local } \\
\text { employee) }\end{array}$ & $\begin{array}{l}\text { Level } 3 \text { (nothing can } \\
\text { be obtained by local } \\
\text { employee) }\end{array}$ \\
\hline \multirow{3}{*}{$\begin{array}{l}\text { Depth of under- } \\
\text { standing }\end{array}$} & A (high) & Very successful & Successful & Failed \\
\hline & $\mathrm{B}$ (medium) & Successful & Quite successful & Failed \\
\hline & $\mathrm{C}$ (low) & Quite successful & Almost failed & Failed \\
\hline
\end{tabular}

Source: developed by authors 
Table 4 Types of capability and operational definition

\begin{tabular}{ll}
\hline Type of capability & Definition \\
\hline Operational/production capability & Capability to conduct routines or basic activities from adop- \\
& tion / use of new technology; mostly supported by explicit \\
& knowledge \\
& Capability to perform innovative activities and/or create a \\
Innovation capability & new, unique 'product'; mostly built from tacit knowledge; \\
& supported by operational capability \\
\hline
\end{tabular}

Source: adapted from Figuerido et al., (2010)

\section{Results}

This section discusses several case studies in Indonesian local firms to show how the concept of KTR works as the basic foundation of strategy for knowledge transfer. This part consists of six case studies in Indonesian manufacturing companies which employed expatriate with expertise in engineering area. The case studies was conducted through observation and interviews with local employees, expatriates, and other related parties in each case study, described the implementation of KTR in achieving KT quality in regard with the changes in the nature of expatriation. In the following section, each case was analyzed in terms of the causal relationship for each dimension and variables to show the mechanism on how each firm responded the changing nature of expatriation. Comparison among cases was also conducted to analyze the necessary condition to cope with the changing nature and the mechanism on how to achieve knowledge transfer quality (KTQ) as a measure of success level based on KTR framework. Cases with multiple expatriates and/or local employees only considered the final results of the interactions.

The results shows variation between different conditions that affect the KT. Results of the six case studies and how KTR works to form relationship qualities and knowledge transfer qualities for the case studies are shown in Table 5, 6, 7, 8, 9.From the six case studies described, it can be seen that there are several levels of achievement in successful KT. The important thing in knowledge transfer quality is knowledge accuracy. If the transferred knowledge is not the expected knowledge, then there is no useful knowledge transferred and the KT will obviously fail. Meanwhile, the amount of knowledge and the depth of understanding can vary in several levels.

In further, it appears that successful cases generally occur in companies with good organizational readiness in all of its aspects. Both companies also had high readiness to transfer, although it was not perfect in all aspects. The low aspect was seen in cultural intelligence, which if explored further was related to the ability of foreign languages from local workers. Nevertheless, these language barriers could be overcome by using images/picture/engineering drawing and formulas -that commonly used in engineering area, which could be utilized by local staff as a medium for communicating knowledge with the expatriates. Besides, in both cases, the 
Table 5 General information of the case studies

\begin{tabular}{lllllll}
\hline Category & Case study 1 & Case study & Case study 3 & Case study 4 & Case study 5 & $\begin{array}{l}\text { Case study } \\
6\end{array}$ \\
\hline $\begin{array}{c}\text { Expatriate's } \\
\text { country } \\
\text { origin }\end{array}$ & Spain & $\begin{array}{c}\text { Japan, Tai- } \\
\text { wan }\end{array}$ & China & Korea & Japan & China \\
$\begin{array}{c}\text { Number of } \\
\text { expatriate }\end{array}$ & 2 & 14 & 30 & 1 & 1 & 2 \\
$\begin{array}{c}\text { Reassign- } \\
\text { ment/ } \\
\text { repatriation }\end{array}$ & Repatriation & Repatriation & $\begin{array}{c}\text { Reassign- } \\
\text { ment }\end{array}$ & $\begin{array}{c}\text { Reassign- } \\
\text { ment }\end{array}$ & $\begin{array}{c}\text { Reassign- } \\
\text { ment }\end{array}$ & Repatriation \\
\hline
\end{tabular}

communication skills of the expatriates seemed to play an important role in grasping the intention of the local employees.

Another successful case-even though the success level was still below the level of case 2 and case 6 -was seen in the case study 1 . In this case, the company had perfect organizational readiness, but not all aspects of readiness to accept and to transfer were strong. Both the source and the recipient of the knowledge faced obstacles: the knowledge base of the expatriate was still lacking because he did not have production experience, while the recipient's cultural intelligence was not too high. However, the company could still innovate even though the KT was not at a very successful level. This was possible due to the strong knowledge base and ACAP from local employees which enabled the creation of innovation.

Other quite successful cases (cases with success level below the three earlier case studies) occurred in case study 4 and 5 although there was only little difference in the context of their success. In case study 4, KT succeeded in transferring important knowledge and it was sufficient for operational capability even though it was just an ordinary routine. Because local personnel had low understanding towards the transferred, they could not create their own innovation without the expatriate. In this company, all aspects in organizational readiness, especially in terms of performance appraisal, was very lacking. In terms of readiness to transfer, the expatriates had weaknesses in sub-aspects of cultural intelligence, knowledge base, and openness in knowledge sharing. The cultural intelligence in this case was related to

Table 6 Knowledge transfer quality and its results of assessment for the case studies

\begin{tabular}{|c|c|c|c|c|}
\hline \multicolumn{2}{|c|}{$\begin{array}{l}\text { Knowledge Transfer Quality } \\
\text { Amount and accuracy of } \\
\text { knowledge }\end{array}$} & \multirow{2}{*}{$\begin{array}{l}\text { Level } 1 \text { (all expected } \\
\text { knowledge can be } \\
\text { obtained by local } \\
\text { employee) }\end{array}$} & \multirow[t]{2}{*}{$\begin{array}{l}\text { Level } 2 \text { (only a part of } \\
\text { knowledge can be obtained } \\
\text { by local employee) }\end{array}$} & \multirow{2}{*}{$\begin{array}{l}\text { Level } 3 \text { (nothing } \\
\text { can be obtained by } \\
\text { local employee) } \\
\text { Fail }\end{array}$} \\
\hline $\begin{array}{l}\text { Depth of under- } \\
\text { standing }\end{array}$ & A (high) & & & \\
\hline & B (medium) & Successful & $\begin{array}{l}\text { Quite successful } \\
\text { (case study } 4,5 \text { ) }\end{array}$ & Fail \\
\hline & $\mathrm{C}$ (low) & Quite successful & $\begin{array}{l}\text { Almost fail } \\
\text { (case study 3) }\end{array}$ & Fail \\
\hline
\end{tabular}




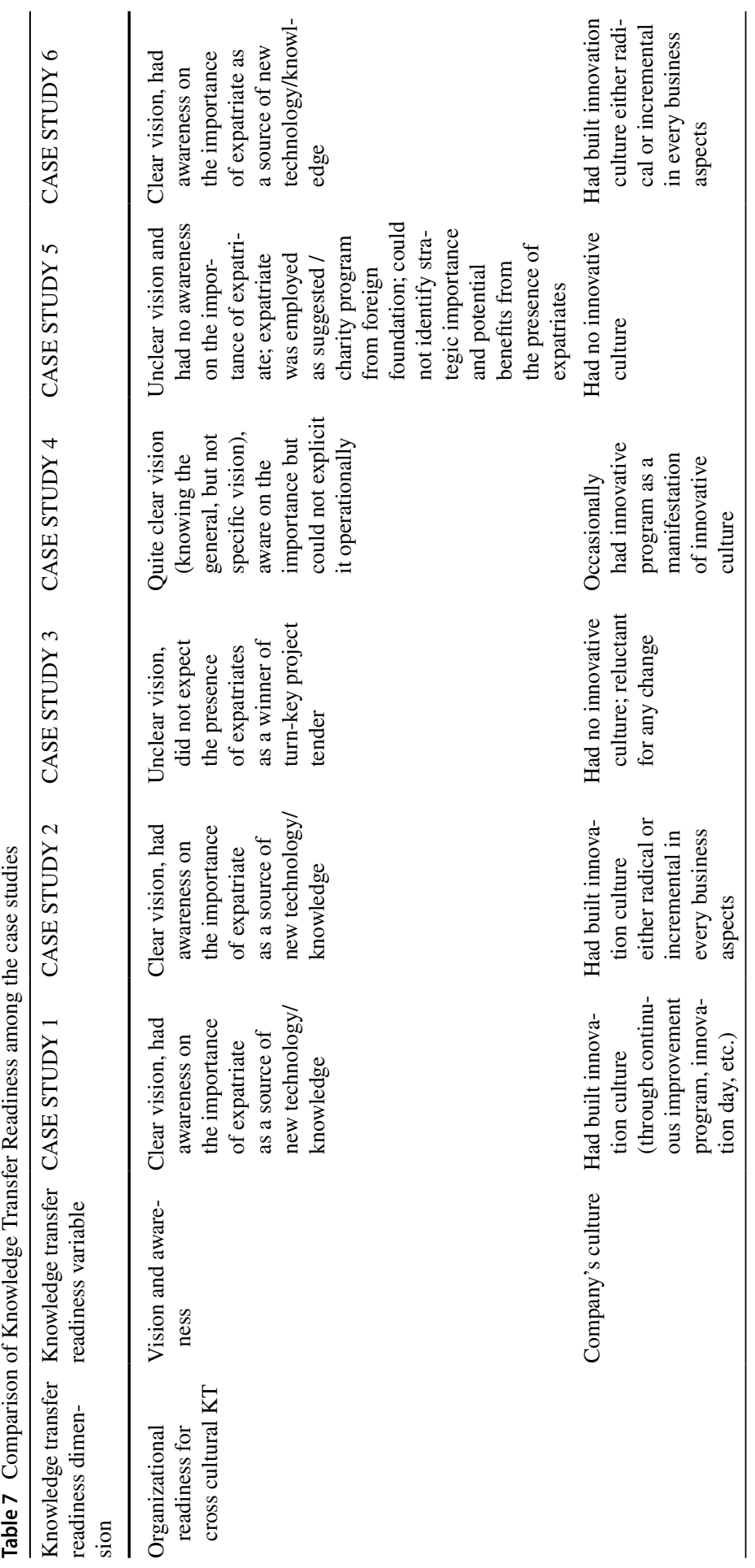




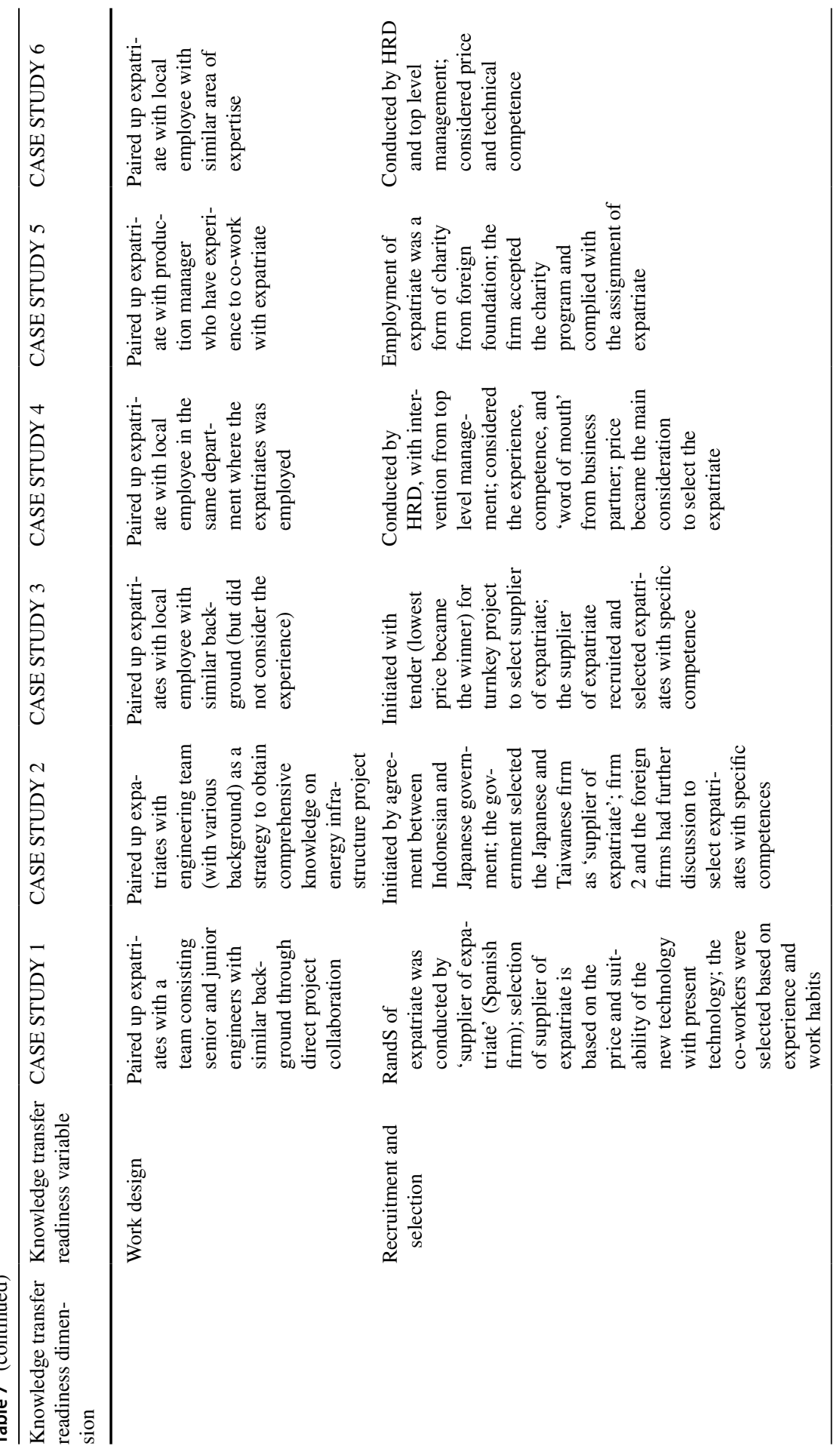




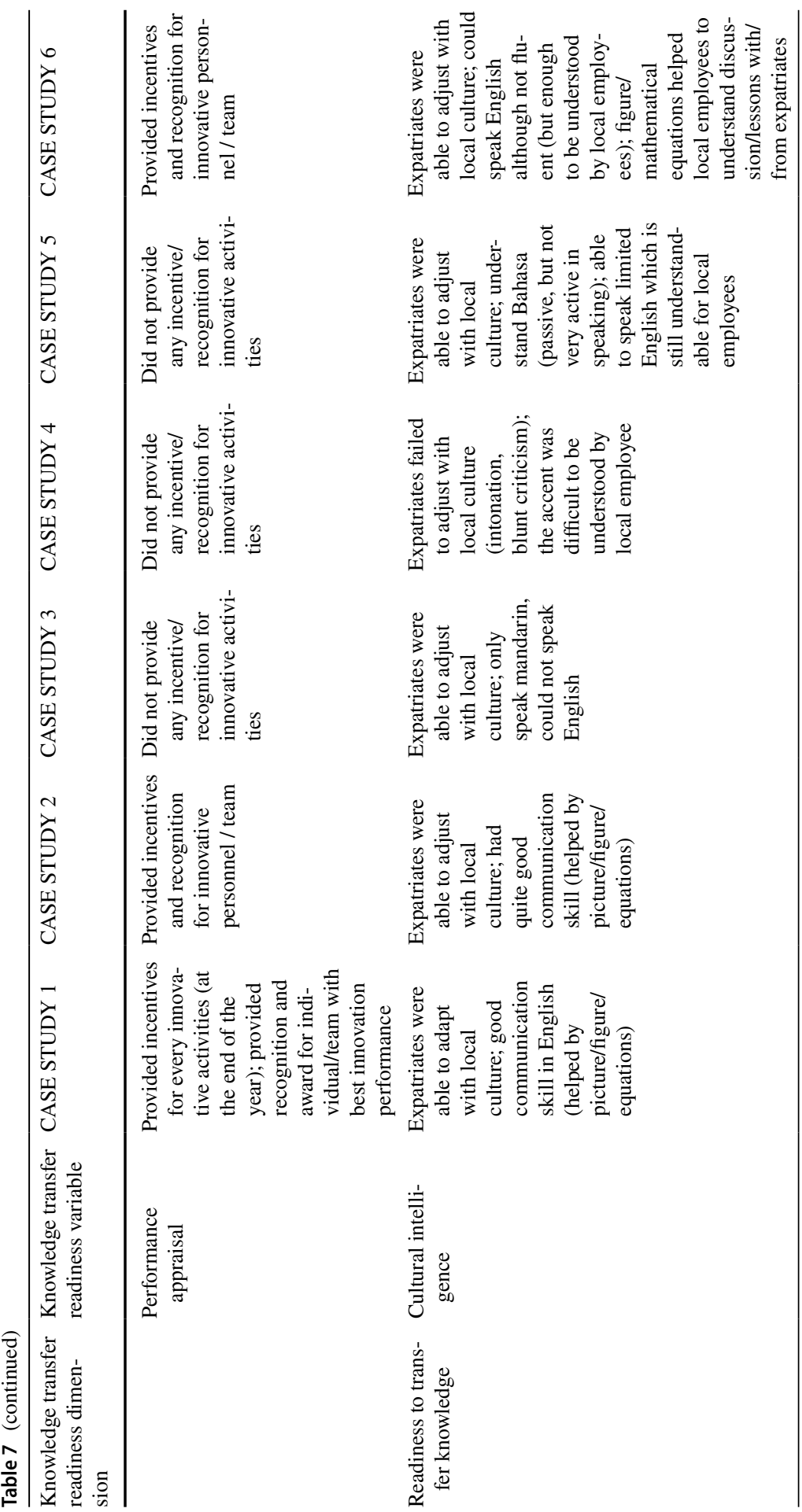




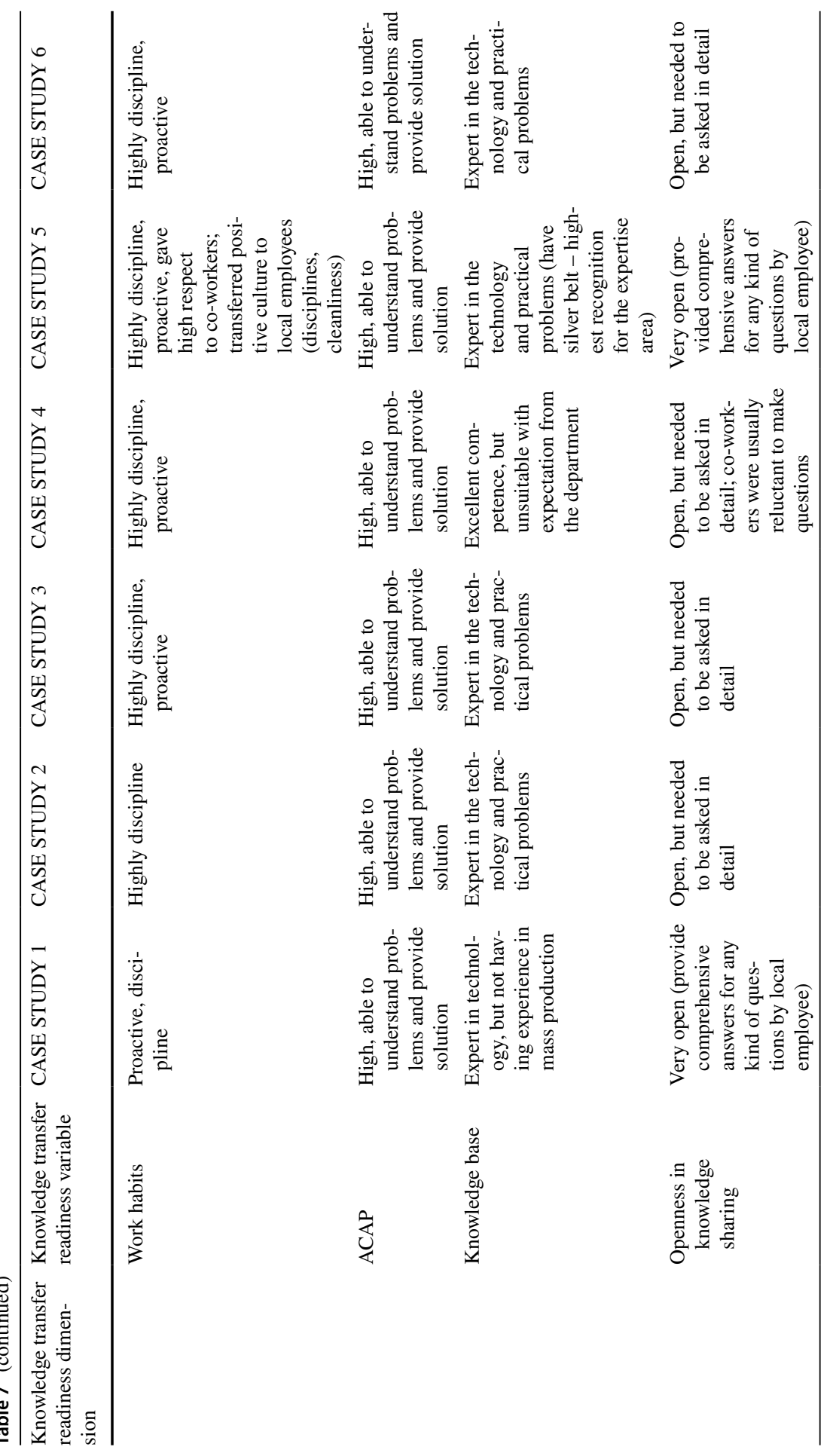




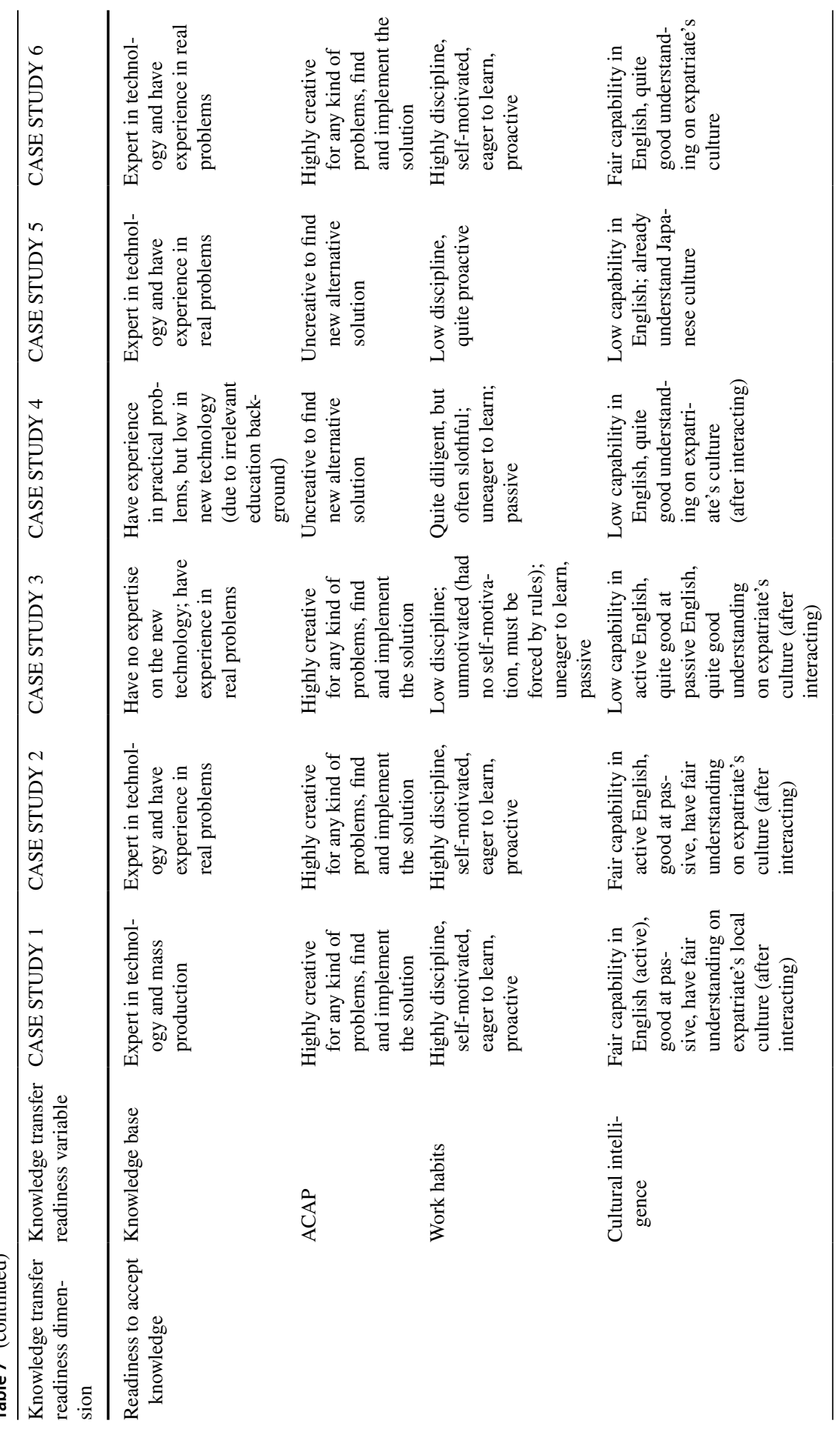




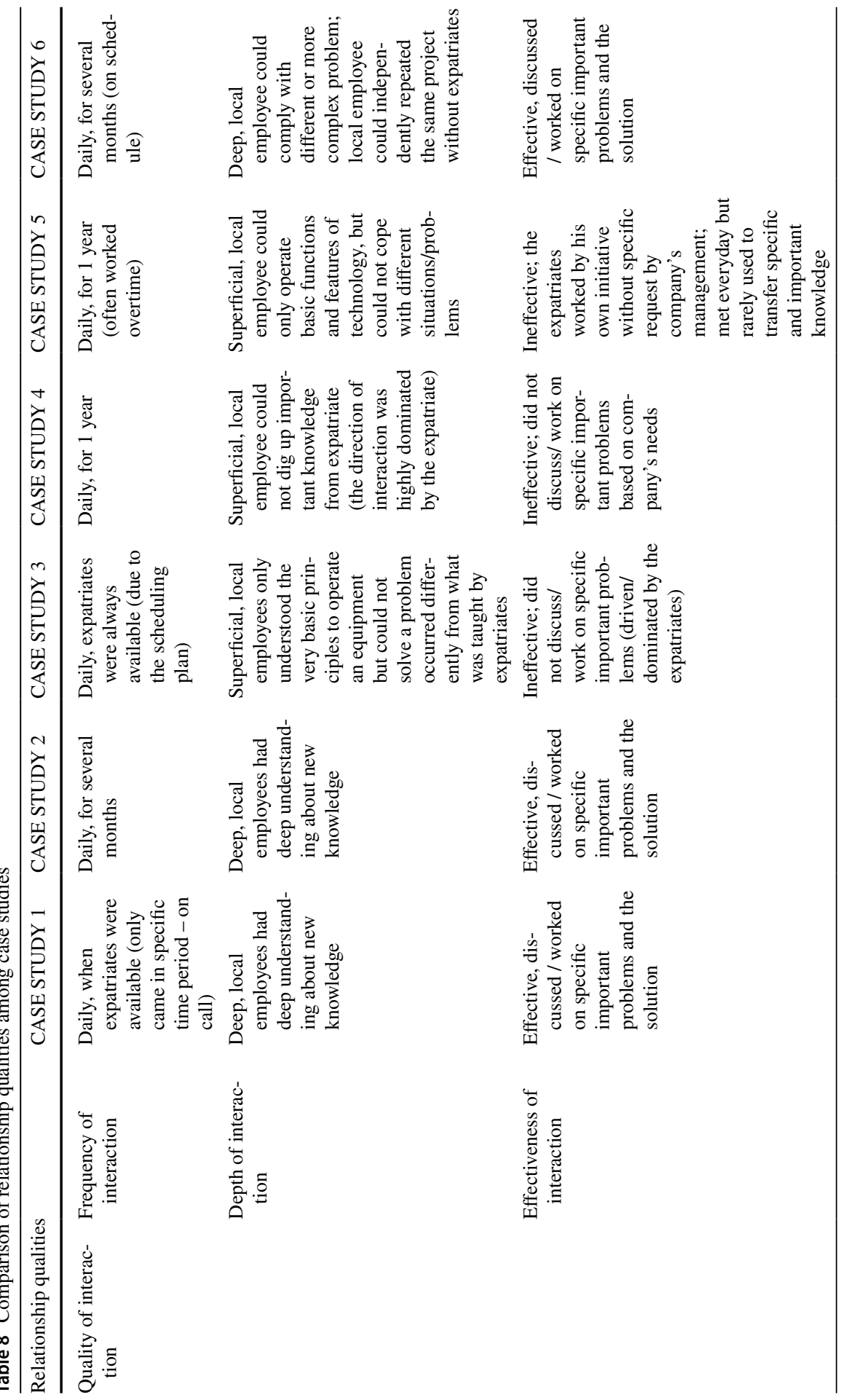




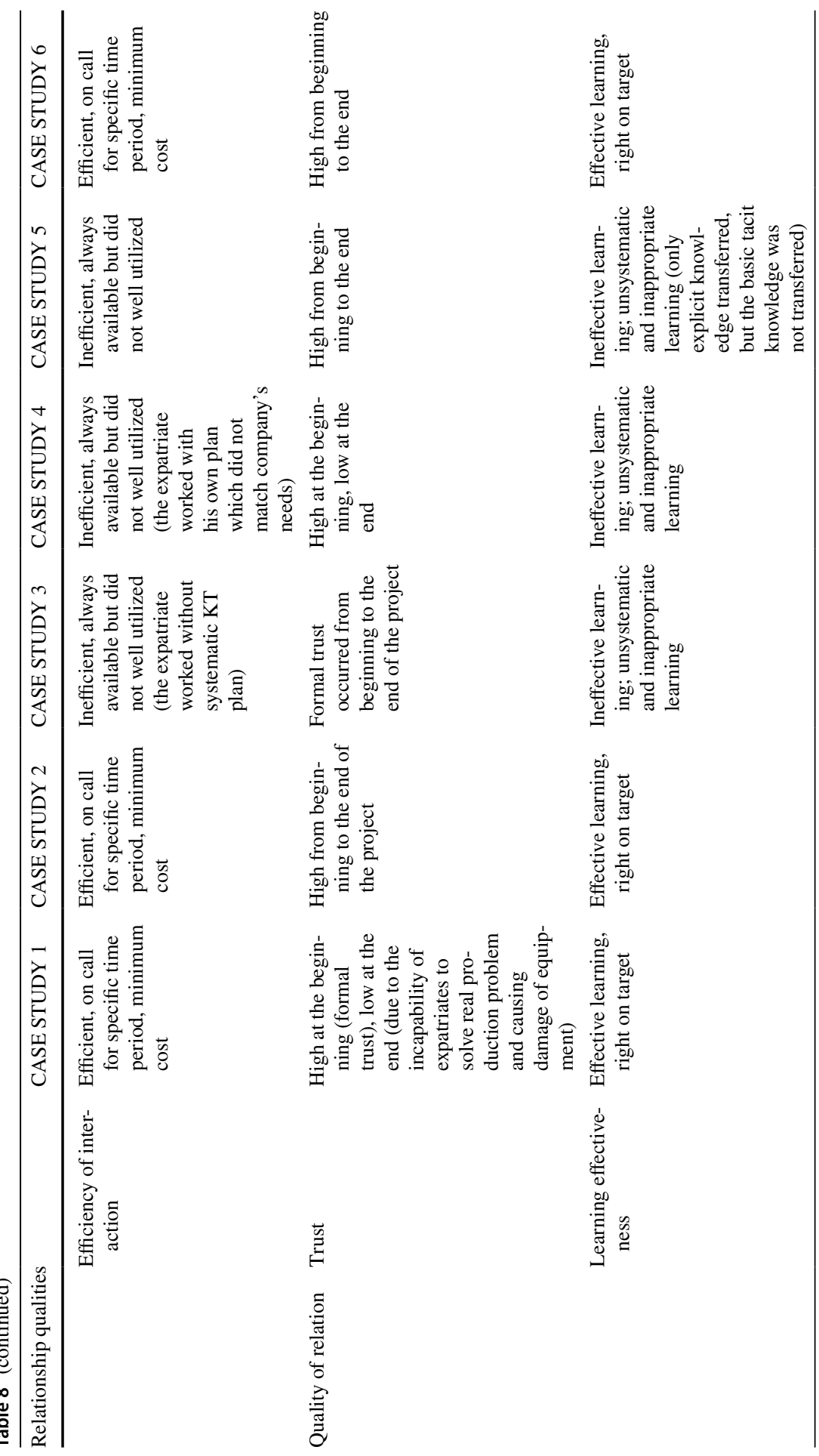




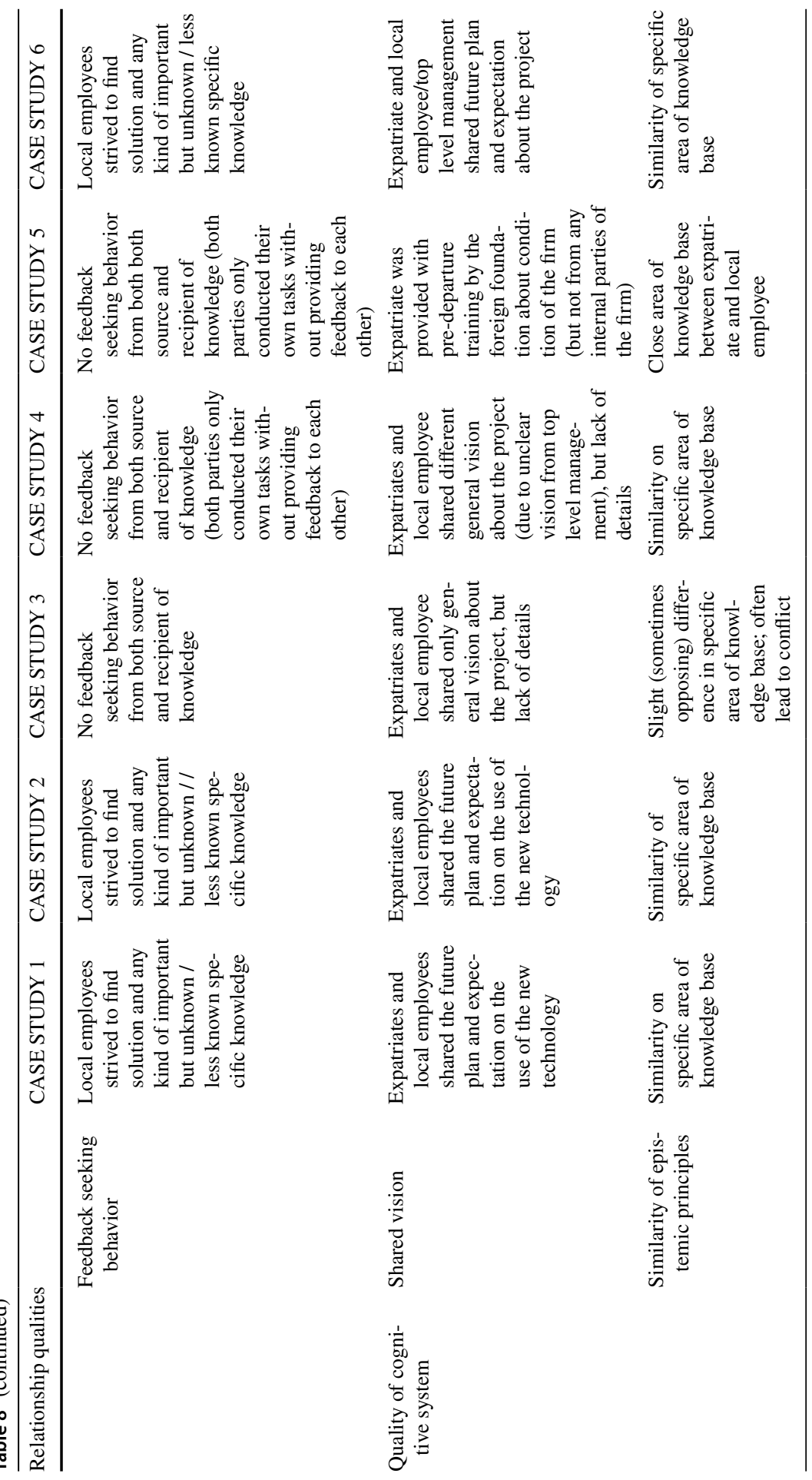




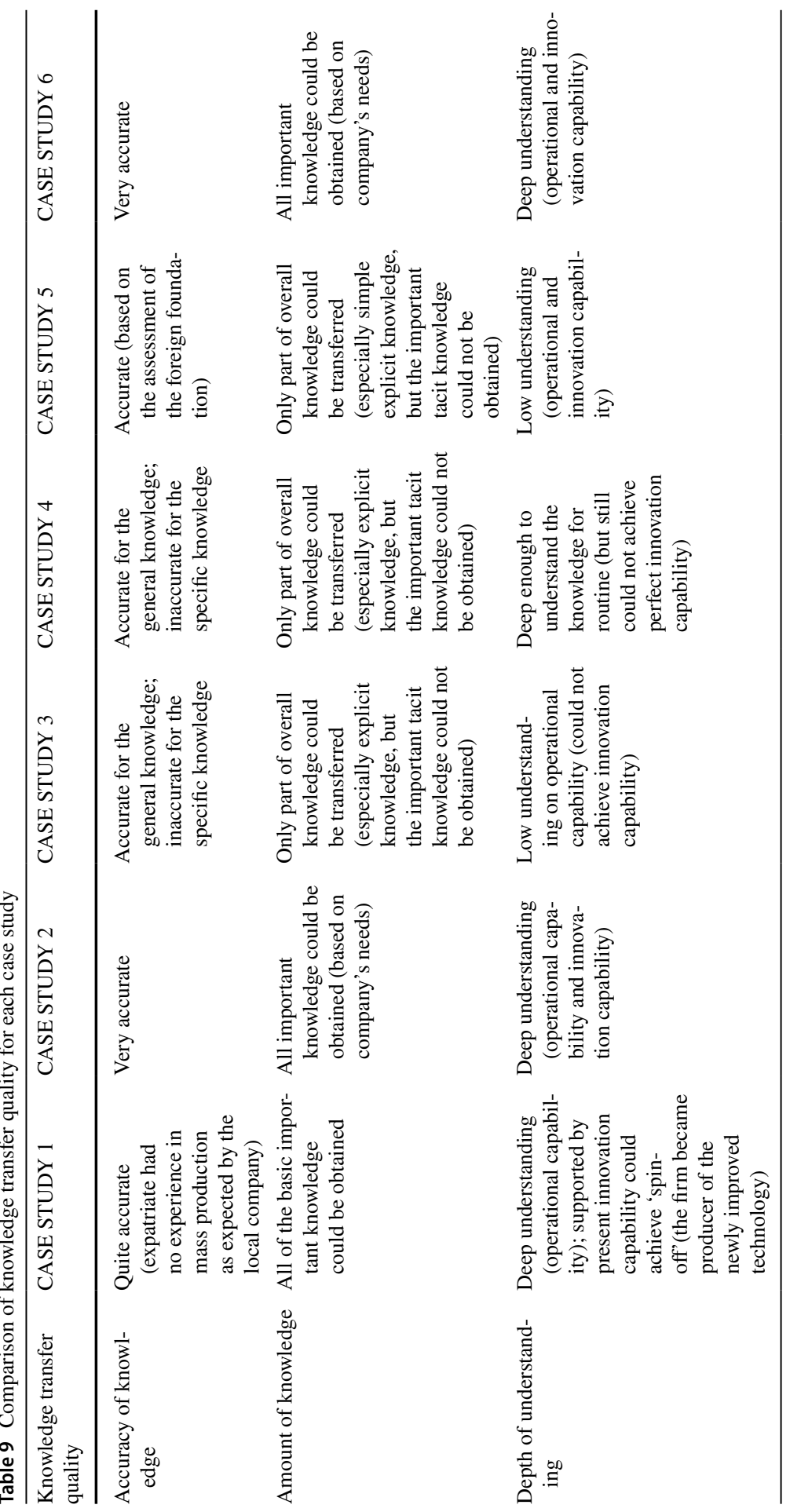


understanding local culture, especially regarding the way of speaking. The Korean expatriate used to be direct in addressing criticism, which could not be too well accepted in Indonesian culture. The knowledge base area owned by the expatriate itself was also considered not suitable with the company's needs. In terms of knowledge sharing, the expatriate tended to resist sharing knowledge needed by the local employees. The condition worsened due to the low condition of readiness to accept knowledge in almost all of its aspects, even very low in terms of cultural intelligence. The knowledge base owned by the local employee was insufficient to receive knowledge. The work habits of local workers who were lack of discipline also made the expatriate often frustrated and reluctant to interact. In respect of cultural intelligence, local workers experienced difficulty in understanding the culture of foreign workers who used to speak in a high-pitched tone and straightforward manner.

Another case with almost similar level of success with case study 4 is case study 5. However, in case study 5, the company had low vision and awareness due to the dominance of external parties and also low organizational readiness. This resulted in less optimal interaction between expatriates and local employees. However, the KT occurred could transfer simple operational capability, driven by initiatives from expatriates who proactively carried out their role as sources of knowledge. Expatriates even carried a positive culture, especially in terms of discipline and environmental cleanliness which was also an important element of innovation culture.

Case study 3 shows KT that almost led to failure. The case study illustrated KT with little knowledge received and low understanding of the knowledge transferred from expatriates. This was mainly due to the weak organizational base of readiness in the aspects of vision and awareness, and the absence of performance appraisal in the company. Lack of vision and awareness caused the expatriation process to run ineffectively and inefficiently, and also caused the difficulty to overcome language barriers. However, the KT did not miserably fail because of the proactive attitude of the expatriates who continued to carry out their tasks despite the work habits of the local employees. This condition formed low relationship qualities in its several aspects which brought impact on KTQ.

\section{Discussion}

Based on the results of the case study, it appears that a successful KT from expatriate to local employees required readiness to transfer regarding cultural intelligence, work habits, ACAP, knowledge base, and openness in knowledge sharing, while the dimension readiness to accept required knowledge base, ACAP, work habits, and cultural intelligence. Compared to (Hsu, 2012), there are differences in supporting elements in each dimension. (Hsu, 2012) incorporates elements from the source and recipient sides in the personal qualities dimension. Based on the results of this study, the elements from the source and recipient side that show the readiness needed in conducting KT were not similar. The elements that must be owned by both parties are cultural intelligence, knowledge base, work habits, and ACAP. Meanwhile, an additional element of expatriate is related to openness in knowledge sharing. This supports the findings of (Riege 2005), who mentioned that lack of transparency can 
be a barrier in knowledge sharing, where knowledge sharing itself is an important part of KT.

Although readiness to transfer and readiness to accept are important in KT, the condition occurred in the source and the recipient was supported from the organizational readiness side. (Hsu, 2012) alluded to these aspects in organizational practice, especially regarding collaborative-based HR configuration. Align with (Hsu 2008), the results of this study showed the importance of readiness in terms of work design and performance appraisal which also includes compensation. Nevertheless, contradict with Hsu, the results of this study showed that both elements did not always have to be group-based but it could occur individually. This depended on the condition of each company and the similarity and adequacy of knowledge base of the individual who became the recipient. In the case of local companies in Indonesia, the training element was not a factor that must always occurred dominantly and well prepared. In Indonesia, this was not always done properly due to limited financial resources and limited time, and also the factor of government policies that cannot be controlled by the company. This is the basic principle of KTR concept, which includes how to achieve a successful KT with various limitations that make changes in the nature of expatriation. This research also identified the importance of innovation culture that became a prerequisite for the running of a targeted KT. It also encourages innovation, recruitment and selection that can at least capture the 'most important elements' for optimal KT results based on the defined goals.

KTR affects relationship qualities which further affect KTQ. In relation with the indicator of successful KT where such success is often indicated by repatriation which often indicates that the expatriate's service is no longer needed, this research argued that occasionally, repatriation occurred due to the inability of the expatriate to meet the early expectation of the company that employ them. Therefore, it is suggested that KTQ is used as the measurement indicator of successful KT which includes accuracy of knowledge, amount of knowledge, and depth of understanding. Accuracy of knowledge describes the acquisition of 'the right knowledge' required, while the amount of knowledge illustrates the adequacy of knowledge to change from the initial condition to the better one in terms of ownership of knowledge. Although there is knowledge transferred from the expatriate to the local employees, it cannot be directly concluded as successful KT without the fulfillment of minimum requirements. Regarding the success level of KT, it is suggested to conduct further research using quantitative assessment. KT level in this study still has weaknesses in defining the success rate for absolute comparisons.

Associated with (Szulanski, 1996), who indirectly indicated that KT has been successful when it has passed various phases of KT, this study found that although all phases have been passed and there has been knowledge transferred, this research sees that three aspects in the KTQ needed to be looked at further at the end of the process. This ensures that all minimal knowledge required has been internalized and transferred to the receiver. However, this research still requires future research, especially to review further the three dimensions as measurement of the KTQ. Also, to look at the borderline of all three dimensions to determine the minimum requirements to achieve successful KT. The development of more 
definitive or quantitative measurement methods with clear distinction of indicators is also needed.

Each element in the dimensions of KTR had an influence on the elements in the relationship qualities dimension which ultimately impacted the KTQ. Different from (Hsu, 2012) who only looked at the frequency of interaction as the attribute of interaction, the results of this study showed other elements, namely depth of interaction, effectiveness and efficiency of interaction. It is argued that high frequency of interaction does not always create a good quality of interaction that contributes to the change of expatriation nature.

Based on the results of the case studies, it can be concluded that even without frequent interaction, local company could still achieve a good KTQ and produce a successful KT. The effectiveness and efficiency of interaction, sufficient depth of interaction, and supported by the 'just in time' presence of expatriate play important role in the process of KT. The quality of interaction mutually affected the quality of relations, especially with the formation of trust, learning effectiveness, and feedback seeking behavior. This condition was supported by the elements in the dimension of readiness to transfer and to accept knowledge. With the appropriate cultural intelligence, the adequacy of ACAP, the suitability of work habits from the source and the recipient, and also coupled with openness in knowledge sharing, the trust from both parties would be formed which thus creating feedback seeking behavior. Although the frequency of interaction is not very high, those elements can generate conducive conditions for deep comprehension and effective learning.

Looking deeper at the trust element, it was found in the Case Study 1 and Case study 4 that trust might change from the beginning to the end of KT process. This occurred in terms of the belief on what the other party is able to give what he/she has promised earlier, either in technical matters or in relation with the suitability of the knowledge base. This certainly needs to be anticipated from the beginning of the RandS process. Therefore, future research is needed to look deeper at this aspect.

Quality of relations seemed to be influenced by the quality of cognitive system, where the similarity of epistemic principles was determined by the similarity of the area of knowledge base of the source and recipient. The differences in the knowledge base could create conflicts that would ultimately prevent the building of feedback seeking behavior. Meanwhile, the shared vision element of the company's management, especially from the beginning of the interaction also affected the effectiveness of learning. With a clear synchronized vision at the beginning of the KT process, both knowledge source and recipient could make adjustment throughout the process, which then indirectly affect the quality of interaction.

The condition of relationship qualities could eventually influence KTQ, where the 'resultant' of its dimensions can be categorized into several levels. There were various conditions experienced by the case studies, as well as their achievements and supporting KTR elements.

Condition of the elements in the KTR influenced achievement in innovation capability. Based on the case studies, it was found that there are several firms that reach only operational capability while others could attain innovation capability. It seemed that the achievement for operational capability and innovation capability needed different elements of relationship qualities (Fig. 6 and 7). Based on these findings, it 


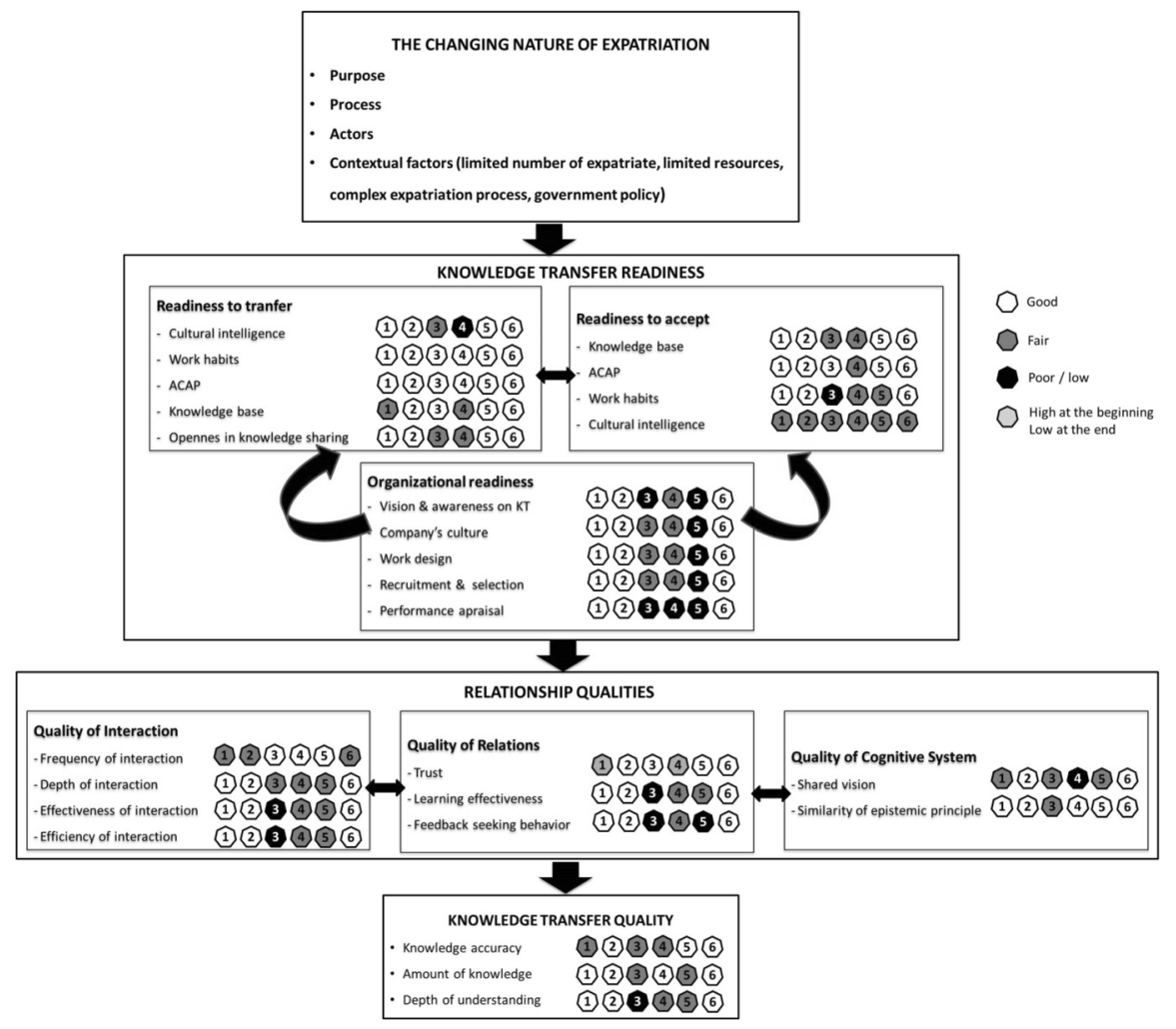

Fig. 5 Knowledge transfer readiness, relationship qualities, and KTQ achievement in the case studies

can be concluded that sufficient elements of KTR was needed to achieve innovation capability. However, as shown in Fig. 5, not all elements should be perfectly fulfilled. This was the 'consequences' of various things resulting in the changing nature. The elements of the organizational readiness included the shared vision that completed and became important in preparing the readiness to transfer, and also form the effectiveness and the efficiency for shaping the readiness to accept. This also indicated that Indonesian local firms invited expatriates to be involved in innovation process (Abbate et al., 2013) and not only for its routines.

The readiness to transfer itself was interrelated with the readiness to accept. This occurred due to the fact that the process of innovation capability needed the similarity of epistemic principles, learning effectiveness, feedback seeking behavior, trust, and the depth of interaction. This brings more advance explanation to the concept of capability formation (Teece \& Pisano, 1994; Teece et al., 1997). This research explained the process of capability development in which the elements within KTR would form different elements of relationship qualities that are needed in developing different type of capabilities. The result of this research showed the presence of path complementarity and paths substitution in building 
READINESS TO TRANSFER

- Cultural intelligence (cultural adaptation; communication skill)

- Work habits

- Knowledge base

- Openness in knowledge sharing

\section{READINESS TO ACCEPT}

- ACAP

- Work habits

- Knowledge base

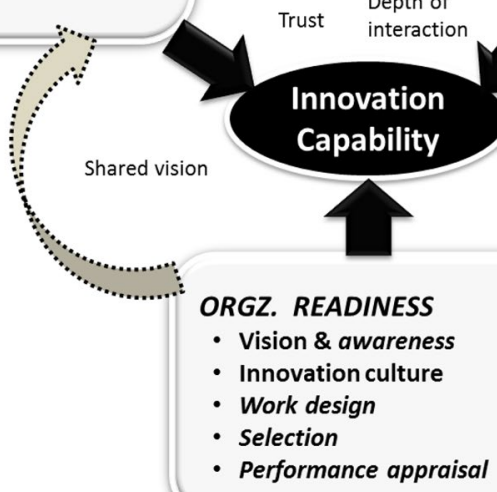

Fig. 6 Knowledge transfer readiness to achieve innovation capability

the interactions between expatriates and the local employees which then finally create the operational capability and/or the innovation capability.

If there was a changing nature of expatriation causing obstacles in recruiting the right expatriate, then different aspects/elements were required as minimum prerequisites to produce a successful $\mathrm{KT}$, as indicated by sufficiency in KTQ (Fig. 5, 6, and 7).In this research, the sufficiency was shown by qualitative

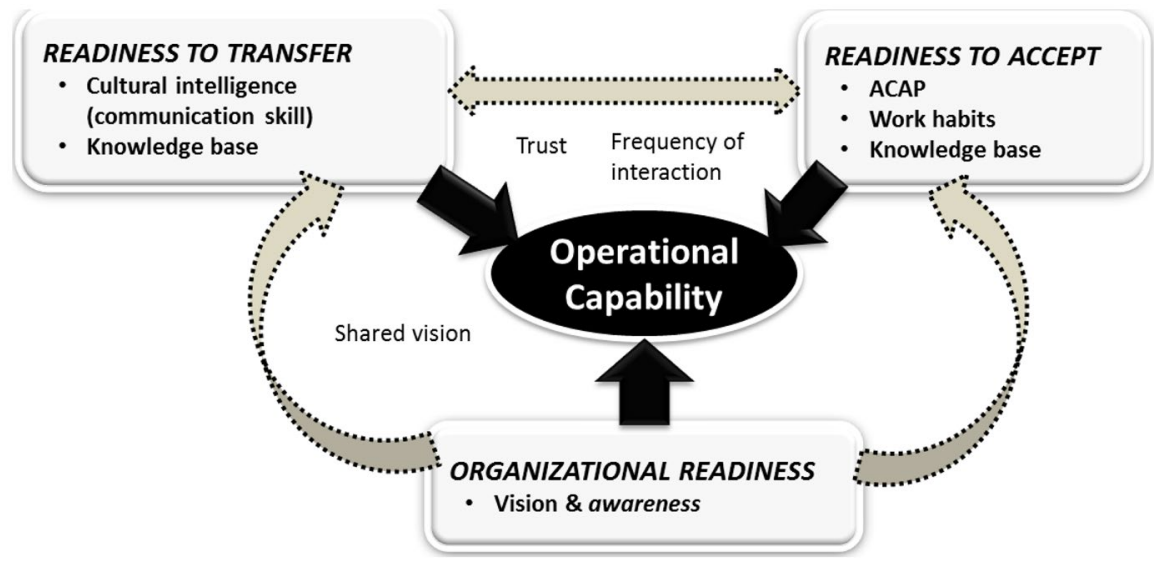

Fig. 7 Knowledge transfer readiness to achieve operational capability 
assessment for each dimension of KTQ. At least one KTQ's element should be in 'fair' condition and other two should be in good level. Based on this study, it appeared that the weaknesses of expatriate could arise from the lack of cultural intelligence, knowledge base, and openness in knowledge sharing (Fig. 5). However, such shortcomings did not prevent the achievement of successful KT. This is supported by the condition of local employees with particular characteristics shown in the readiness to accept. Whereas the knowledge base and the cultural intelligence of expatriate were not in good condition, this weakness could be overcome by the knowledge base and the cultural intelligence of the local employee. Meanwhile, the openness in knowledge sharing of expatriate and the ACAP of both parties can be seen as compulsory prerequisite for conducting successful KT.

Furthermore, in KT it is important to have the 'right' knowledge in sufficient amount and not merely achieving 'as much knowledge as possible'. When the knowledge could be well understood, its spin-off possibility might increase as occurred in Case study 1 . In the case study, the company became the new competitor with better technology compared to the origin company (Spanish firm) which sent the expatriates. This supports the work of (Del Giudice et al., 2013) who correlated the 'right' knowledge and the spin-off. However, more case studies are still needed to provide stronger justification.

A good organizational readiness in all elements became an essential requirement for achieving a very successful KT. Poor organizational readiness could put high risk in failing the process of KT, indicated by two or more elements of KTQ in fair condition or at least one element in bad state even if the two others were in good condition. This research argued that organizational readiness was a precondition for achieving sufficiency of readiness to transfer and readiness to accept. If the organization readiness was not fulfilled or the required elements conditions were too weak, the company should reconsider to recruit expatriate to perform KT. This was related to the effectiveness of KT. As argued by (Zulkifli et al., 2019) who presented several guiding principles for planning effective KT, this research confirms that organizations should take a holistic approach to KT that considers such factors, particularly cultural diversity and learning style. However, this research suggests further studies to see how much expatriate's home country has effects in fulfilling the condition of elements from each dimension of KTR. In this study, there were differences in expatriate's character between/among countries, and it was indicated that this was not merely a difference in individual character but also related to the characteristics of cultural nature of the expatriate's origin. In addition, this study also confirmed the principle of 'one size does not fit all' which explains that each organization would have unique needs and therefore required unique solutions. These were shown by the different conditions of each case study in Indonesian local firms that was caused by the changing nature of expatriation. Therefore, each of the local firms needed different solutions to strive for excellent KTQ which also defined the operational and innovation capability.

Different from (Zulkifli et al., 2019), the results of this study pointed out that the source and recipient of knowledge were not always be involved in every stage of the KT process. The most important principles was 'just in time', meaning the 
expatriates presented whenever they were needed by the firms, either to save costs for the expatriation or to provide time and opportunities for the local employees to identify the knowledge that have not been mastered. This was supported by the vision and awareness from company's management which applied in KT process. Therefore, this research supports the work of (Raudeliūnienè et al., 2016) who stated that individual and organizational factors significantly contribute to the efficiency of such process. Nevertheless, this study also saw that those factors were important to achieve effectiveness, especially to find 'the right knowledge' and the sufficient depth of understanding.

In addition, communication included in the cultural intelligence was not the only key factor for an effective KT. Communications could be an obstacle for KT, especially when expatriate did not master host country's local / national language. In fact, the Indonesian local firms did not consider it as a barrier when certain condition can be fulfilled. These obstacles could be removed if local employee has good cultural intelligence, especially good language skills and ability to understand expatriate's culture. In particular, the engineering field uses more figures/pictures/engineering drawings and mathematical equations in its routine. Therefore, this could help the communication non-verbally.

When the condition of the local employees was not supportive but the company had enough resources to recruit expatriate, the company could easily hire ideal expatriate as long as they were available in the labor market. This could compensate the shortcomings from local employee's side. However, due to the limitations of the case studies, further research is still needed to explore the limitations of local employee's conditions that can be covered by the excellence of expatriate. Meanwhile, organizational readiness condition became a compulsory requirement to meet the conditions that allow the sources to transfer knowledge to the recipient, so that relationship qualities can be developed and the expected KTQ can be achieved.

Different from the concept of KMR (Sutan \& Bach, 2015), KTR has more specific focus, especially on three dimensions, including the readiness to transfer and to accept knowledge. These dimensions showed the important characteristics embedded in the source (the expatriate) and the receivers of knowledge (the local employee). While KMR has more focus on organizational management activities and intellectual capital as well as technological aspects which categorized as macro condition.

Compared to (Valmohammadi \& Amidi, 2020) who discuss about change readiness in the context of knowledge acquisition, the KTR has broader range which is not only include the 'soft' aspect but also indicates the 'infrastructure' which needs to be supported by company's management but with specific context on KT from expatriate to local employee. The KTR have wider area which is not only included the knowledge acquisition, but also attempts to achieve the mastery of the knowledge. The KTR do not only consider 'the positive' elements but also enable to consider about 'how to' achieve optimum results from the limitations on the elements which are embedded to the expatriate, the local employee, and the organization which assigned both parties.

This study suggests that if there are too many 'unready' elements (more than 1 element in each dimension of KTR) especially from local employee, then the 
employment of expatriates needs to be postponed until the firms and employees are ready enough. If this condition is not met, then it will only waste the organization's financial resources without getting expected results. This may have implications to the government's policy, specifically on expatriate's entry permits. If the expected result is solely for KT for innovation then the design of RandS and work design is still important to be implemented as prerequisites of entry permits. However, if there is another purpose to hire expatriates from government, especially for investment purposes, then the prerequisites is no longer necessary. Therefore, future research is needed to examine the optimization of pull-outs between KT's interests and the investments. Another challenge for HRD and management in the company is in terms of ensuring this readiness at the beginning for each aspect in the dimensions as best as possible. However, this often cannot fully be controlled, so it is also necessary to think about adjustment strategies in the middle of the process.

\section{Conclusion}

KTR can be defined as the ability of a unit to be prepared, willing to, conducting, and benefiting from KT activity, especially to transfer knowledge from expatriate to local employee. Compared to other readiness concepts regarding knowledge management and also the concept of integration of various determining factors of KT success, as well as KT plan, this concept focuses more on the readiness of the source and the recipient in carrying out the KT process with particular support from organizational readiness. This concept was built to help organization to achieve successful KT that experiences several limitations because of the changing nature of expatriation, as occurred to Indonesian local companies. From the case studies, it can be concluded that to achieve a successful KT, not all of elements in KTR are compulsory. These aspects become the advantage of the KTR, and these are not accommodated by other concepts, such as KT plan, KMR, or change readiness for knowledge acquisition. However, this concept needs to look at every element in detail and then arrange them into specific strategies which are considered to be different for each organization.

There are several conditions when the readiness to transfer cannot be met perfectly. Nevertheless, these conditions can still be overcome by the fulfillment of readiness to accept if the readiness to transfer is not in perfect condition, and vice versa. It absolutely needs to be supported by organizational readiness, which can enable coordination so as to create integration in various processes / stages and in the systems of the organization. This condition is needed in order to achieve innovation capability, after operational capability is fully attained. The needs for readiness of both types of capability are different. There are more elements in KTR and relationship qualities which need to be built to accomplish complete innovation capability compared to those dedicated to achieve operational capability.

Based on the results of the case studies in Indonesian local companies, there are several elements of readiness from the source or recipient side that cannot be fully complied. Then, to be able to achieve a successful KT, the elements from the recipient side should be in ideal conditions, and vice versa. This can be happened on 
the elements of the cultural intelligence and the similarity of the area of knowledge base. Meanwhile, there were elements that both parties must comply with, in terms of adequacy of the ACAP and similarity of the work habits. The element of openness in knowledge sharing becomes an element that must exist in the source side as a part of the 'readiness to transfer'. These lead to practical matters regarding recruitment and selection of expatriates and selection of the co-worker for the expatriates. To embody these into action in firms, the other dimension in KTR, namely organizational readiness becomes very important. This dimension greatly determines the success of KT and plays a great role in determining the two other dimensions of KTR due to its relation to technical selection of expatriates and the co-workers. All of the three dimensions will determine the fulfillment of conditions related to KT readiness that will influence the relationship qualities to achieve KTQ as an alternative to qualitative measurement of the KT success level.

KTQ can be an alternative measure of KT success because it is related to the fulfillment of the objectives of KT from expatriates. KTQ can be a new option of qualitative indicator to measure the success of KT. KTQ embraces three dimensions which include the amount of knowledge, the accuracy of knowledge, and the depth of understanding. A quite successful KT must at least reach a level of sufficiency (fair) for minimum two dimensions in KTQ, with the other one dimension in 'good' condition. Whilst, a successful KTQ must at least meet two dimensions in 'good' condition, with another dimension not in poor condition. The high frequency of interaction between expatriate and local employees does not always produce a good KTQ, but it is more determined by the effectiveness and efficiency of interactions and the depth of interaction. In this case, the principle of 'just in time' interaction looks more promising and leads to more efficient and effective resource utilization. This condition is influenced by various KTR elements and interactions among these elements.

\section{References}

Abbate, T., Coppolino, R., \& Schiavone, F. (2013). Linking Entities in Knowledge Transfer: The Innovation Intermediaries. Journal of the Knowledge Economy, 4(3), 233-243.

Aboelmaged, M. G. (2014). Predicting e-readiness at firm-level: An analysis of technological, organizational and environmental (TOE) effects on e-maintenance readiness in manufacturing firms. International Journal of Information Management, 34(5), 639-651.

Al-Alawi, A. I., Al-Marzooqi, N. Y., \& Mohammed, Y. F. (2007). Organizational culture and knowledge sharing:critical success factors. Journal of Knowledge Management, 11(2), 22-42.

Alexander, A. T., \& Childe, S. J. (2013). Innovation: a knowledge transfer perspective. Production Planning and Control: The Management of Operations, 24(2-3), 208-225.

Ang, S., \& Van Dyne, L. (2008). Conceptualization of cultural intelligence. In S. Ang, \& L. Van Dyne (Eds.), Handbook of cultural intelligence: Theory, measurement, and applications. Armonk: M.E. Sharpe, Inc.

Argote, L., \& Ingram, P. (2000). Knowledge transfer: A basis for competitive advantage in firms. Organizational Behavior and Human Decision Processes, 82(1), 150-169.

Attar, M. M. (2020). Organizational Culture, Knowledge Sharing, and Intellectual Capital: Directions for Future Research. International Journal of Business and Economics Research, 9(1), 11-20. 
Berger, P. L., \& Luckmann, T. (1996). The Social Construction of Reality A Treatise in the Sociology of Knowledge. Penguin Books.

Bonache, J., Brewster, C., Suutari, V., \& de Saa', P. (2010). Expatriation: Traditional Criticisms and International Careers. Thunderbird International Business Review, 52(4), 263-274.

Busch, P. (1967). Tacit knowledge in organizational learning. Hershey, PA : IGI Pub.

Caballé, S., Xhafa, F., Daradoumis, T., \& Abraham, A. (2008). Efficient Interaction Analysis for an Effective Provision of Knowledge about the Discussion Process to CSCL Practices. The 7th Computer Information Systems and Industrial Management Applications, 269-274 https://doi.org/10.1109/ CISIM.2008.592008.59

Cassiman, B., \& Veugelers, R. (2006). In search of complementarity in innovation strategy: internal RandD and external knowledge acquisition. Management Science, 52(1), 68-82.

Chang, S., Yen, D. C., Ng, C. S., \& Chang, W. (2012). An analysis of IT/IS outsourcing provider selection for small- and medium-sized enterprises in Taiwan. Information and Management, 49(5), 199-209.

Charmaz, K. (2006). Constructing grounded theory. A practical guide through qualitative analysis. Sage.

Chow, C. W., Deng, F. J., \& Ho, J. L. (2000). The Openness of Knowledge Sharing within Organizations: A Comparative Study of the United States and the People's Republic of China. Journal of Management Accounting Research, 65.

Cicourel, A. V. (1973). Cognitive Sociology: Language and Meaning in Social Interaction. Penguin.

Cohen, M., March, J., \& Olsen, J. (1972). A Garbage Can Model of Organizational Choice. Administrative Science Quarterly, 17(1), 1-25.

Cohen, W. M., \& Levinthal, D. A. (1990). Absorptive Capacity: A New Perspective on Learning and Innovation. Administrative Quarterly, 35(1990), 128-152.

Davenport, T. H., \& Prusak, L. (1998). Working knowledge: how organizations manage what they know. Harvard Business School Press.

Del Giudice, M., Della Peruta, M. R., \& Maggioni, V. (2013). The 'Right' Knowledge and Spin-off Processes: an Empirical Analysis on Knowledge Transfer. Journal of the Knowledge Economy, 4(2013), 304-318.

Disterer, G. (2001). Individual and Social Barriers to Knowledge Transfer. Proceedings of the 34th Hawaii International Conference on System Sciences ,2001, Pp 1-7

Dixon, N. M. (2000). Common knowledge: How companies thrive by sharing what they know. Harvard Business School Press.

Downes, M., \& Thomas, A. (2000). Knowledge Transfer Through Expatriation: The U-curve Approach To Overseas Staffing. Journal of Managerial Issues, 12(2), 131-149.

Figueiredo, P. N., Gomes, S., \& Farias, R. (2010). Innovative technological capability in firms of the tourism sector: a study of the hotels in the city of Rio de Janeiro during the 1990-2008 period. Revista de Administração Pública, 44(5), 1139-1170.

Foss, N.J., Minbaeva, D.B., Pedersen, T., \& Reinholt, M. (2009). Encouraging Knowledge Sharing Among Employees: How Job Design Matters. Human Resource Management, November-December 2009, 48 (6), 871- 893

Freiling, J., \& Fichtner, H. (2010). Organizational culture as the glue between people and organization: A competence-based view on learning and competence building. Zeitschrift für Personalforschung, 24(2), 152-172

Gal, Y., \& Gal, A. (2019). Knowledge Bias: Neo-feudalism and Other Reasons to Avoid Sharing Knowledge by Knowledge Workers. Journal of the Knowledge Economy, 10, 826-848.

Grant, R. M. (1996). Prospering in Dynamically-Competitive Environments: Organizational Capability as Knowledge Integration. Organization Science, 7(4), 375-387.

Harris, H., \& Brewster, C. (1999). The coffee-machine system: how international selection really works. The International Journal of Human Resource Management, 10(3), 488-500.

Hsu, I. (2008). Knowledge sharing practices as facilitating factor for improving organizational performance through human capital: A preliminary study. Experts Systems with Applications, 35(2008), 1316-1326.

Hsu, Y.S. (2012). Knowledge Transfer between Expatriates and Host Country Nationals: A Social Capital Perspective, Thesis and Dissertation. University of Wisconsin-Milwaukee.

Inkpen, A. C., \& Tsang, E. W. K. (2005). Social Capital, Networks, and Knowledge Transfer. The Academy of Management Review, 30(1), 146-165.

Ismail, M. (2015). Conceptualizing knowledge transfer between expatriates and host country nationals: The mediating effect of social capital. Cogent Business and Management, 2(1), 1-16. 
Karim, D. N., \& Majid, A. H. B. (2018). Autonomous job design and knowledge sharing behavior: the mediating role of public service motivation. International Journal of Economics, Commerce and Management, VI, 4, 607-622.

Kowalska-Styczen, A., Malarz, K., \& Paradowski, K. (2018). Model of Knowledge Transfer Within an Organisation. Journal of Artificial Societies and Social Simulation, 21 (2) 3. https://doi.org/10.18564/ jasss.3659.Retrieved from http://jasss.soc.surrey.ac.ukuk/21/2/3.html

Kühlmann, T., \& Hutchings, K. (2010). Expatriate assignments vs localization of management in China: Staffing choices of Australian and German companies. Career Development International, 15(1), 20-38.

Lane, P. J., Salk, J. E., \& Lyles, M. A. (2001). Absorptive capacity, learning, and performance ininternational joint ventures. Strategic Management Journal, 22(2001), 1139-1161.

Lawson, B., \& Samson, D. (2001). Developing Innovation Capability in Organisations: A Dynamic Capabilities Approach. International Journal of Innovation Management, 5(3), 377-400.

Lee, K., \& Lim, C. (2001). Technological Regimes, Catching-up and Leapfrogging: the Findings from the Korean Industries. Research Policy, 30(3), 459-483.

Maxwell, J. A. (2005). Qualitative research design:an interactive approach (2nd ed.). Sage.

Maxwell, J. A. (2012). A realist approach for qualitative research. Sage.

Nahapiet, J., \& Ghoshal, S. (1998). The Academy of Management Review., 23(2), 242-266.

Oddou, G., Osland, J. S., \& Blakeney, R. N. (2009). Repatriating knowledge: Variables influencing the "transfer" process. Journal of International Business Studies, 40(2009), 181-199.

Oliveira, M.J.S.P., \& Pinheiro, P. (2020). Factors and barriers to tacit knowledge sharing in non-profit organizations - A case study of volunteer firefighters in Portugal. Journal of The Knowledge Economy. https://doi.org/10.1007/s13132-020-00665-x

Parasuraman, A. (2000). Technology readiness index (TRI): A multiple-item scale to measure readiness to embrace new technologies. Journal of Service Research, 2(4), 307-321. In Vize, R., Coughlan, J., Kennedy, A., and Ellis-Chadwick (2013). Industrial Marketing Management, 42 (2013), 909-918.

Parcero, O. J., and Ryan, J. C. (2017). Becoming a Knowledge Economy: the Case of Qatar, UAE, and 17 Benchmark Countries. Journal of the Knowledge Economy, 8(2017), 1146-1173.

Prasada, R.A. (2014). Transfer Pengetahuan dan Teknologi dari Tenaga Kerja Asing Kepada Tenaga Kerja Pendamping (Studi Kasus pada PT Apac Inti Corpora, Semarang). Working Paper. Universitas Kristen Satya Wacana.

Prihadyanti, D., et al. (2019). Expatriation process in Indonesian local firms. Advances in Economics, Business, and Management Research, 72(2019), 147-153.

Rahman, M. H., Moonesar, I. A., Hossain, M. M., \& Islam, M. Z. (2018). Influence of organizational culture on knowledge transfer: Evidence from the Government of Dubai. Journal of public affairs - Special Issue: Value Creation in Knowledge Intensive Institutions: Priorities for Governance and Public Affairs, 18(1), 1-13.

Ramaswamy, V. (2009). Leading the transformation to co-creation of value. Strategy and Leadership, $37(2), 32-37$.

Raudeliūnienè, J., Meidutė-Kavaliauskienè, I., \& Vileikis, K. (2016). Evaluation of factors determining the efficiency of knowledge sharing process in the Lithuanian National Defence System. Journal of The Knowledge Economy, 7(2016), 842-857.

Reardon, R., Lavis, J., \& Gibson, J. (2006). From Research to Practice: A Knowledge Transfer Planning Guide (2006). Downloaded from https://www.iwh.on.ca/tools-and-guides/from-research-to-practicekte-planning-guide (retrieved on 31 January 2021).

Riege, A. (2005). Three dozen knowledge sharing barriers managers must consider. Journal of Knowledge Management, 9(3), 18-35.

Rutter, J. (2001). From the sociology of trust towards a sociology of 'E-trust'. International Journal of New Product Development and Innovation Management, 2 (4), 385-399.

Riusala, K., \& Suutari, V. (2004). International knowledge transfers through expatriates. Thunderbird International Business Review, 46(6), 743-770.

Singley, M. K., \& Anderson, J. R. (1989). The transfer of cognitive skill. Harvard University Press. In Argote, L. and Fahrenkopf, E. (2016). Knowledge transfer in organizations: The roles of members, tasks, tools, and networks. Organizational Behavior and Human Decision Processes, 136(2016), $146-159$.

Strauss, A.L., \& Corbin, J. (1994). Grounded theory methodology: An overview. In N.K. Denzin and Y.S. Lincoln (Eds). Handbook of qualitative research. Thousand oaks. CA: Sage Publications. 
Sultan, A., \& Bach, C. (2015). Knowledge Management Readiness In Organizations. International Journal of Scientific and Technology Research, 4(6), 99-102.

Szulanski, G. (1996). Exploring internal stickiness: impediments to the transfer of best practice within the firm. Strategic Management Journal, 17(Winter Special Issue), 27-43.

Szulanski, G. (2003). Sticky Knowledge : Barriers to Knowing in the Firm. Sage.

Teece, D. J. (1976). The Multinational Corporation and the Resource Cost of International Technology Transfer. Ballinger.

Teece, D. \& Pisano, G. (1994). The dynamic capabilities of firms: an introduction. Industrial and Corporate Change, 3(3), 537-556.

Teece, D. F., Pisano, G., \& Shuen, A. (1997). Dynamic capabilities and strategic management. Strategic Management Journal, 18(7), 509-533.

Tortoriello, M. (2014). The social underpinnings of absorptive capacity: The moderating effects of structural holes on innovation generation based on external knowledge. Strategic Management Journal, 36(4), 586-597.

Tsai, W., \& Ghoshal, S. (1998). Social Capital and Value Creation: The Role of Intrafirm Networks. Academy of Management Journal, 41(1998), 464-476.

Valmohammadi, C., \& Amidi, M. (2020). Modeling influence of change readiness on knowledge acquisition process: A case study. Cognitive Systems Research, 61(2020), 14-31.

VandeWalle, D. (2003). A goal orientation model of feedback-seeking behavior. Human Resource Management Review, 13(2003), 581-604.

Vize, R., Coughlan, J., Kennedy, A., \& Ellis-Chadwick (2013). Industrial Marketing Management, 42, 909-918.

Wei, Y., \& Miraglia, S. (2017). Organizational culture and knowledge transfer in project-based organizations: Theoretical insights from a Chinese construction firm. International Journal of Project Management, 35(2017), 571-585.

Weidenfeld, A., Williams, A. M., \& Butler, R. W. (2010). Knowledge transfer and innovation among attractions. Annals of Tourism Research, 37(3), 604-626.

Wenger, E., McDermott, R., \& Snyder, W. (2002). Cultivating Communities of Practice: A Guide to Managing Knowledge. Harvard Business School Press.

Yin, R. K. (2003). Case study research: Design and methods. Sage.

Zahra, S.A., \& George, G. (2002). Absorptive capacity: A review, reconceptualization, and extension. The Academy of Management Review, 27(2), 185-203.

Zulkifly, N. A., Ismail, M., \& Hamzah, S. R. (2019). Predictors of knowledge transfer between expatriates and host country nationals: Shared vision as mediator. European Journal of Management and Business Economics, 29(2), 199-215.

Publisher's Note Springer Nature remains neutral with regard to jurisdictional claims in published maps and institutional affiliations. 